\title{
Identification of Ectodomain Regions Contributing to Gating, Deactivation, and Resensitization of Purinergic P2X Receptors
}

\author{
Hana Zemkova, Mu-Lan He, Taka-aki Koshimizu, and Stanko S. Stojilkovic \\ Section on Cellular Signaling, Endocrinology and Reproduction Research Branch, National Institute of Child Health and Human Development, National \\ Institutes of Health, Bethesda, Maryland 20892-4510
}

\begin{abstract}
The P2X receptors (P2XRs) are a family of ligand-gated channels activated by extracellular ATP through a sequence of conformational transitions between closed, open, and desensitized states. In this study, we examined the dependence of the activity of P2XRs on ectodomain structure and agonist potency. Experiments were done in human embryonic kidney 293 cells expressing rat $\mathrm{P} 2 \mathrm{X}_{2 \mathrm{a}} \mathrm{R}, \mathrm{P} 2 \mathrm{X}_{2 \mathrm{~b}} \mathrm{R}$, and $\mathrm{P} 2 \mathrm{X}_{3} \mathrm{R}$, and chimeras having the V60-R180 or V60-F301 ectodomain sequences of $\mathrm{P} 2 \mathrm{X}_{3} \mathrm{R}$ instead of the I66-H192 or I66-Y310 sequences of $\mathrm{P} 2 \mathrm{X}_{2 \mathrm{a}} \mathrm{R}$ and $\mathrm{P} 2 \mathrm{X}_{2 \mathrm{~b}} \mathrm{R}$. Chimeric $\mathrm{P} 2 \mathrm{X}_{2 \mathrm{a}} / \mathrm{V} 60-\mathrm{F} 301 \mathrm{X}_{3} \mathrm{R}$ and $\mathrm{P} 2 \mathrm{X}_{2 \mathrm{~b}} / \mathrm{V} 60-\mathrm{F} 301 \mathrm{X}_{3} \mathrm{R}$ inherited the $\mathrm{P} 2 \mathrm{X}_{3} \mathrm{R}$ ligand-selective profile, whereas the potency of agonists for $\mathrm{P} 2 \mathrm{X}_{2 \mathrm{a}} / \mathrm{V} 60-\mathrm{R} 180 \mathrm{X}_{3} \mathrm{R}$ was in between those observed at parental receptors. Furthermore, $\mathrm{P} 2 \mathrm{X}_{2 \mathrm{a}} / \mathrm{V} 60$ -

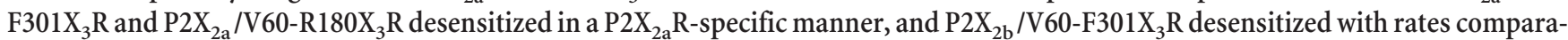

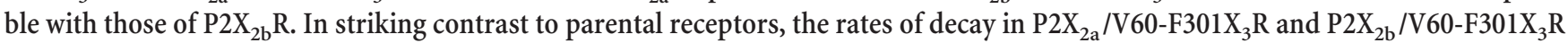
currents after agonist withdrawal were 15 - to 200 -fold slower. For these chimeras, the decays in currents were not dependent on duration of stimuli and reflected both continuous desensitization and deactivation of receptors. Also, participation of deactivation in closure of channels inversely correlated with potency of agonists to activate receptors. The delay in deactivation was practically abolished in

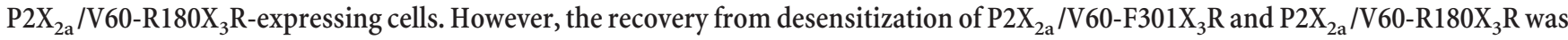
similar and substantially delayed compared with that of parental receptors. These results indicate that both ectodomain halves participate in gating, but that the $\mathrm{C}$ and $\mathrm{N}$ halves influence the stability of open and desensitized conformation states, respectively, which in turn reflects on rates of receptor deactivation and resensitization.
\end{abstract}

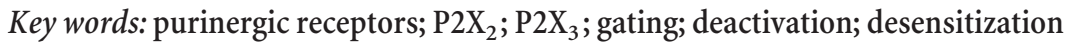

\section{Introduction}

Purinergic P2 receptors (P2XRs) are a family of ion-conducting channels that activate and desensitize in response to the binding of ATP to the extracellular ligand-binding domain, and deactivate and resensitize after washout of agonist. The P2XR subunits are composed of two transmembrane domains, placing most of the protein extracellularly and the $\mathrm{N}$ and $\mathrm{C}$ termini intracellularly. The trimeric assembly of subunits most likely accounts for formation of functional P2XR channels (Nicke et al., 1998), and two to three molecules of ATP are required to activate receptor (Bean, 1990). In the absence of crystallographic data, the dependence of conformation transitions between resting, conducting, and desensitized states on P2XR structure have been incompletely understood (North, 2002). P2XRs differ in their sensitiv-

\footnotetext{
Received March 11, 2004; revised June 5, 2004; accepted June 8, 2004. We thank Dr. Melanija Tomic for critical reading of this manuscript.

Correspondence should be addressed to Dr. Stanko Stojilkovic, Endocrinology and Reproduction Research Branch, National Institute of Child Health and Human Development, National Institutes of Health, Building 49, Room 6A-36, 49 Convent Drive, Bethesda, MD 20892-4510. E-mail: stankos@helix.nih.gov.

H. Zemkova's present address: Institute of Physiology, Academy of Sciences of the Czech Republic, 14220 Prague 4, Czech Republic.

DOI:10.1523/JNEUROSCI.1471-04.2004

Copyright $\odot 2004$ Society for Neuroscience $\quad$ 0270-6474/04/246968-11\$15.00/0
}

ity for ATP with $\mathrm{EC}_{50}$ values in the following order: $\mathrm{P} 2 \mathrm{X}_{1} \mathrm{R}=$ $\mathrm{P} 2 \mathrm{X}_{3} \mathrm{R}<\mathrm{P} 2 \mathrm{X}_{2} \mathrm{R}<\mathrm{P} 2 \mathrm{X}_{4} \mathrm{R}=\mathrm{P} 2 \mathrm{X}_{5} \mathrm{R}<\mathrm{P} 2 \mathrm{X}_{6} \mathrm{R} \ll \mathrm{P} 2 \mathrm{X}_{7} \mathrm{R}$. There are other pharmacological distinctions among receptors, such as the sensitivity to $\alpha \beta$-methylene-ATP and antagonists (Khakh et al., 2001), suggesting the structural specificity of the ligandbinding pocket. The ATP binding site was partially characterized (Jiang et al., 2001; Roberts and Evans, 2004), and P2XR ectodomain also contains sites for antagonists and modulators (GarciaGuzman et al., 1997; Clarke et al., 2000; Coddou et al., 2003). The relevance of residues that line the channel walls was also studied (Rassendren et al., 1997; Egan et al., 1998).

Receptors differ in their desensitization rates: $\mathrm{P} 2 \mathrm{X}_{1} \mathrm{R}$ and $\mathrm{P} 2 \mathrm{X}_{3} \mathrm{R}$ desensitize rapidly, and $\mathrm{P} 2 \mathrm{X}_{4} \mathrm{R}$ and $\mathrm{P} 2 \mathrm{X}_{5} \mathrm{R}$ desensitize with moderate rates, whereas $\mathrm{P} 2 \mathrm{X}_{2} \mathrm{R}, \mathrm{P} 2 \mathrm{X}_{6} \mathrm{R}$, and $\mathrm{P} 2 \mathrm{X}_{7} \mathrm{R}$ desensitize slowly or do not desensitize (Ralevic and Burnstock, 1998). The site-directed mutagenesis revealed an important role for residues in the C-terminal domain of P2XRs (Brandle et al., 1997; Simon et al., 1997; Koshimizu et al., 1998, 1999). However, other domains also participate in desensitization (Werner et al., 1996; Boue-Grabot et al., 2000). The recovery from desensitization occurs in a minute timescale (North, 2002), but structural elements controlling the desensitized conformation state have not been identified. The deactivation of P2XRs is also incompletely char- 
acterized. In general, for nondesensitizing receptors, the deactivation rate should depend on the kinetics of transition from open to closed states and the rate of ligand dissociation from its binding site (Lester and Jahr, 1992). For P2XR, Rettinger and Schmalzing (2004) suggested that deactivation reflects predominantly the unbinding properties of the agonist. Their conclusion was based on finding that potency of several agonists to activate a nondesensitizing $\mathrm{P} 2 \mathrm{X}_{2} / \mathrm{P} 2 \mathrm{X}_{1}$ chimera inversely correlates with the corresponding time constant of deactivation.

Here, we used the recombinant rat $\mathrm{P} 2 \mathrm{X}_{2 \mathrm{a}} \mathrm{R}, \mathrm{P} 2 \mathrm{X}_{2 \mathrm{~b}} \mathrm{R}$, and $\mathrm{P} 2 \mathrm{X}_{3} \mathrm{R}$, and their chimeras to study the dependence of the activity of channels on ectodomain structure. Our results indicate that changes in the receptor architecture made by chimerization had no obvious effects on receptor activation and kinetics of desensitization. However, chimerization dramatically delayed the deactivation of receptors and recovery from desensitization compared with parental P2XRs. These changes are consistent with a hypothesis that conformational changes associated with channel opening and desensitization trap agonist onto the P2XR and thus represent the rate-limiting steps in the deactivation and resensitization of receptors.

\section{Materials and Methods}

DNA constructs, cell culture, and transfection. The coding sequences of the rat $\mathrm{P} 2 \mathrm{X}_{2 \mathrm{a}}, \mathrm{P} 2 \mathrm{X}_{2 \mathrm{~b}}$, and $\mathrm{P} 2 \mathrm{X}_{3}$ subunits were isolated by reverse transcription-PCR (Koshimizu et al., 1999), and subcloned into the biscistronic enhanced fluorescent protein expression vector pIRES2EGFP (Clontech, Palo Alto, CA) at the restriction enzyme sites of XhoI/ Pst I for $\mathrm{P} 2 \mathrm{X}_{2 \mathrm{a}} \mathrm{R}$ and $\mathrm{P} 2 \mathrm{X}_{2 \mathrm{~b}} \mathrm{R}$, and $\mathrm{XhoI} / E$ co RI for $\mathrm{P} 2 \mathrm{X}_{3} \mathrm{R}$. Chimeric $\mathrm{P} 2 \mathrm{X}_{2 \mathrm{a}} / \mathrm{P} 2 \mathrm{X}_{3}$ and $\mathrm{P} 2 \mathrm{X}_{2 \mathrm{~b}} / \mathrm{P} 2 \mathrm{X}_{3}$ subunits, termed $\mathrm{P} 2 \mathrm{X}_{2 \mathrm{a}} / \mathrm{V} 60-\mathrm{F} 301 \mathrm{X}_{3}$ and $\mathrm{P} 2 \mathrm{X}_{2 \mathrm{~b}} / \mathrm{V} 60-\mathrm{F}_{301 \mathrm{X}_{3}}$, contain the extracellular domain from $\mathrm{Val}^{60}$ to Phe ${ }^{301}$ of $P 2 X_{3} R$ instead of the native Ile ${ }^{66}-$ Tyr $^{310}$ sequence of $P 2 X_{2 a} R$ and $\mathrm{P} 2 \mathrm{X}_{2 \mathrm{~b}} \mathrm{R}$, whereas in the $\mathrm{P} 2 \mathrm{X}_{2 \mathrm{a}} / \mathrm{V} 60-\mathrm{R} 180 \mathrm{X}_{3}$ chimera, the $\mathrm{Val}^{60}$ Arg ${ }^{180}$ sequence of $\mathrm{P} 2 \mathrm{X}_{3} \mathrm{R}$ was substituted for the IIe ${ }^{66}$-His ${ }^{192}$ sequence of $\mathrm{P} 2 \mathrm{X}_{2 \mathrm{a}} \mathrm{R}$ (Fig. 1A). These chimeras were constructed as discussed previously (Koshimizu et al., 2002). The large-scale plasmid DNAs for transfection were prepared using a Qiagen (Hilden, Germany) Plasmid Maxi kit. Human embryonic kidney 293 cells (HEK293 cells) were used in functional studies of wild-type and mutant P2XRs, as previously described (He et al., 2003). HEK293 cells were cultured in MEM supplemented with $10 \%$ horse serum and $100 \mu \mathrm{g} / \mathrm{ml}$ gentamicin. Before the day of transfection, cells were plated on $35 \mathrm{~mm}$ culture dishes. For each dish of cells, transient transfection of expression constructs was conducted using $1 \mu \mathrm{g}$ of DNA and $7 \mu \mathrm{l}$ of Lipofectamine 2000 Reagent (Invitrogen, Carlsbad, CA) in $3 \mathrm{ml}$ of serum-free Opti-MEM. After $6 \mathrm{hr}$ of incubation, the transfection mixture was replaced with normal culture medium. Cells were subjected to experiments $24-48 \mathrm{hr}$ after transfection. Experiments were performed in cells with comparable GFP (green fluorescent protein) fluorescence signals ( $\sim 60$ arbitrary units).

Current measurements. Electrophysiological experiments were performed at room temperature using whole-cell patch-clamp recording techniques. Cells were stimulated with ATP, $\alpha \beta$-methylene-ATP $(\alpha \beta$ meATP), 3'-O-(4-benzoyl)benzoyl-ATP (BzATP), adenosine-5'-O-(3thiotriphosphate) (ATP $\gamma \mathrm{S}$ ), and 2-methylthio-ATP (2MeSATP) (Calbiochem, La Jolla, CA). Agonist-induced currents were recorded using an Axopatch 200B patch-clamp amplifier (Axon Instruments, Union City, CA) and were filtered at $1 \mathrm{kHz}$ using a low-pass Bessel filter and sampled at $2 \mathrm{kHz}$. A $40-70 \%$ series resistance compensation was used. Patch electrodes, fabricated from borosilicate glass (type 1B150F-3; World Precision Instruments, Sarasota, FL) using a Flaming Brown horizontal puller (P-87; Sutter Instruments, Novato, CA), were heat polished to a final tip resistance of 3-5 $\mathrm{M} \Omega$. All of the current records were captured and stored using the pClamp 8 software packages in conjunction with the Digidata 1322A analog-to-digital converter (Axon Instruments). Patch electrodes were filled with a solution containing (in $\mathrm{mM}$ ): $140 \mathrm{KCl}, 0.5 \mathrm{CaCl}_{2}, 1 \mathrm{MgCl}_{2}, 5 \mathrm{EGTA}$, and 10 HEPES; $\mathrm{pH}$ was adjusted with $1 \mathrm{M} \mathrm{KOH}$ to 7.2 . The osmolarity of the internal solutions was 282
$287 \mathrm{mOsm}$. The bath solution contained (in $\mathrm{mm}$ ): $142 \mathrm{NaCl}, 3 \mathrm{KCl}, 1$ $\mathrm{MgCl}_{2}, 2 \mathrm{CaCl}_{2}, 10$ glucose, and 10 HEPES; $\mathrm{pH}$ was adjusted to 7.3 with $1 \mathrm{M} \mathrm{NaOH}$. The osmolarity of this solution was $285-295$ mOsm. A $3 \mathrm{M}$ $\mathrm{KCl}$ agar bridge was placed between the bathing solution and the reference electrode. To avoid the impact of endogenously released ATP on the pattern of current signaling in all of the experiments, cells were perfused at a rate of $\sim 2 \mathrm{ml} / \mathrm{min}$ for at least 10 or $20 \mathrm{~min}$ before recording, depending on receptor subtypes. Agonists were applied for 2-60 sec using a fast gravity-driven microperfusion system (BPS-8; ALA Scientific Instruments, Westbury, NY). The application tip was routinely positioned $\sim 500 \mu \mathrm{m}$ above the recorded cell. Less than $200 \mathrm{msec}$ was required for exchange of solutions around the patched cells, as estimated from altered potassium current $(20-80 \%$ rise time).

Calculations. Concentration-response data were fitted by a fourparameter logistic equation using a nonlinear curve-fitting program that derives the $\mathrm{EC}_{50}$ and Hill's values (Kaleidagraph; Synergy Software, Reading, PA). The profiles of currents evoked by prolonged agonist application (used as a measure of desensitization) and the kinetics of current decay evoked by washout of agonists were fitted by a single exponential function $\left[y=A_{1} \exp (-t / \tau)+P\right]$ or by the sum of two exponentials $\left[y=A_{1} \exp \left(-t / \tau_{1}\right)+A_{2} \exp \left(-t / \tau_{2}\right)+P\right]$ using the program CLAMPFIT 8 (Axon Instruments), where $A_{1}$ and $A_{2}$ are the relative amplitudes of the first and second exponential, $\tau_{1}$ and $\tau_{2}$ are time constants, and $P$ is plateau. The derived time constant for desensitization was labeled $\tau_{\text {des }}$, and for current decay after agonist withdrawal, $\tau_{\text {off }}$ The recovery from desensitization was fitted using the equation $I=I_{\max }[1-$ $\exp \left(t / \tau_{\text {rec }}\right)$ ], where $I$ is the observed peak current response, $I_{\max }$ is the maximum peak current recovery, $t$ is the washing time, and $\tau_{\text {rec }}$ is the recovery time constant. All of the numerical values in the text are reported as mean \pm SEM, and significant differences, with $p<0.05$, were determined by Student's $t$ test.

\section{Results}

\section{The efficacy of purinergic agonists for wild-type and}

\section{chimeric P2XRs}

When expressed in HEK293 cells under identical experimental conditions, parental $\mathrm{P} 2 \mathrm{X}_{2 \mathrm{a}} \mathrm{R}, \mathrm{P} 2 \mathrm{X}_{2 \mathrm{~b}} \mathrm{R}$, and $\mathrm{P} 2 \mathrm{X}_{3} \mathrm{R}$ responded to ATP with a rapid rise in current, with peak amplitude dependent on agonist concentrations. In $\mathrm{P} 2 \mathrm{X}_{2 \mathrm{a}} \mathrm{R}$ - and $\mathrm{P} 2 \mathrm{X}_{2 \mathrm{~b}} \mathrm{R}$-expressing cells, the peak current responses were comparable in individual ATP concentrations studied. Figure $1 B$ illustrates the ATP concentration dependence of current amplitude for both receptor subtypes combined. The threshold ATP concentration required for their activation was $0.1 \mu \mathrm{M}$ and the $\mathrm{EC}_{50}$ value was $2.6 \mu \mathrm{M}$. Other agonists also activated these receptors in a micromolar concentration range, with $\mathrm{EC}_{50}$ values indicated in Figure $1 C$; 2MeSATP was the most potent agonist for $\mathrm{P}_{2} \mathrm{X}_{2}$ Rs, followed by ATP, ATP $\gamma$, and BzATP, whereas $\alpha \beta$-meATP acted at these receptors as a low potency agonist. $\mathrm{P} 2 \mathrm{X}_{3} \mathrm{R}$ also responded to agonist application in a dose-response manner. In our experimental conditions, the threshold concentration of ATP to trigger $\mathrm{P} 2 \mathrm{X}_{3} \mathrm{R}$ current was $3 \mathrm{nM}$, and the half-maximal inward current was produced by $39 \mathrm{~nm}$. Other agonists also activated this receptor in nanomolar concentrations, with $\mathrm{EC}_{50}$ values ranging from 18 to $243 \mathrm{nM}$ in the following order: 2MeSATP $<$ ATP $<$ BzATP $<\alpha \beta$-meATP $<$ ATP $\gamma$ S (Fig. $1 C$ ). The amplitudes of current responses induced by saturating concentrations of all of the agonist were highly comparable for parental receptors, indicating that the maximum fraction of receptors in the active state was close to 1, and that all of the drugs acted as full agonists.

In contrast to parental receptors, there was no experimental possibility to examine the dose-dependent effects of agonists on peak currents in single cells expressing chimeric $\mathrm{P}_{2} \mathrm{X}_{2 \mathrm{a}}$ plus V60$\mathrm{F}_{301 \mathrm{X}_{3}}$ and $\mathrm{P} 2 \mathrm{X}_{2 \mathrm{~b}}$ plus $\mathrm{V} 60-\mathrm{F} 301 \mathrm{X}_{3}$ receptors because of almost irreversible desensitization of a large fraction of receptors after a single agonist application (see below). To generate dose-re- 
A

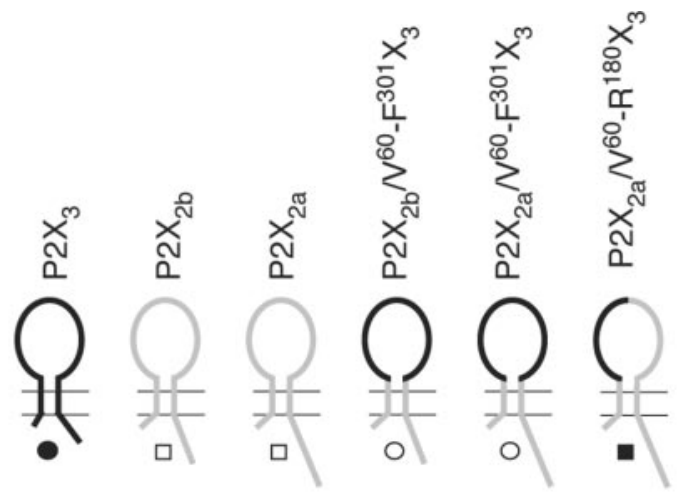

B

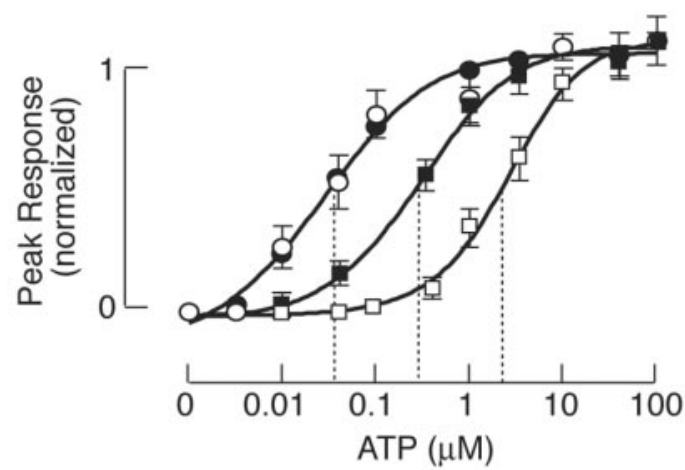

C

\begin{tabular}{lcccc}
\hline Agonists & \multicolumn{4}{c}{$\mathrm{EC}_{50} \mathrm{~s}(\mu \mathrm{M})$} \\
& $\bullet$ & $\square$ & 0 & • \\
\hline \hline 2MeSATP & 0.02 & 1.36 & 0.02 & 0.19 \\
\hline ATP & 0.04 & 2.61 & 0.05 & 0.35 \\
\hline BzATP & 0.07 & 11.59 & 0.09 & 0.67 \\
\hline$\alpha \beta$-meATP & 0.12 & 72.49 & 0.14 & 0.74 \\
\hline ATP $S$ & 0.24 & 7.31 & 0.27 & 0.75
\end{tabular}

Figure 1. Potency of agonists at parental and chimeric P2XRs. A, Schematic representation of the wild-type and chimeric constructs used in this study. For details, see Materials and Methods. $B$, Concentration dependence of ATP-induced peak response in cells expressing wild-type $\mathrm{P} 2 \mathrm{X}_{3}\left(-\right.$ ), wild-type $\mathrm{P} 2 \mathrm{X}_{2 \mathrm{a}}$ and $\mathrm{P} 2 \mathrm{X}_{2 \mathrm{~b}}$ combined $(\square)$, chimeric $\mathrm{P} 2 \mathrm{X}_{2 \mathrm{a}} / \mathrm{V} 60-\mathrm{F} 301 \mathrm{X}_{3}$ and $\mathrm{P} 2 \mathrm{X}_{2 \mathrm{~b}} /$

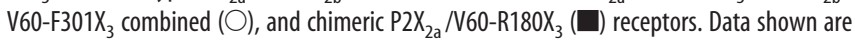
means \pm SEM, $n=5-10$ per dose, and peak amplitudes to $100 \mu \mathrm{m}$ ATP application were used to normalize responses. Dotted lines illustrate $\mathrm{EC}_{50}$ values. $\mathrm{C}_{\text {, The }} \mathrm{EC}_{50}$ values for several agonists of parental and chimeric receptors. Data shown are mean values with SEM within $10 \%$. Cells expressing $\mathrm{P} 2 \mathrm{X}_{2 \mathrm{a}} / \mathrm{V} 60-\mathrm{F}_{301 \mathrm{X}_{3}}$ and $\mathrm{P} 2 \mathrm{X}_{2 \mathrm{~b}} / \mathrm{V} 60-\mathrm{F}_{301 \mathrm{X}_{3}}$ chimeras were stimulated with single agonist concentrations because of their unresponsiveness during repetitive agonist stimulation. The maximum in peak responses of $\mathrm{P} 2 \mathrm{X}_{2} \mathrm{Rs}, \mathrm{P} 2 \mathrm{X}_{3} \mathrm{R}$, and $\mathrm{P} 2 \mathrm{X}_{2 \mathrm{a}} / \mathrm{V} 60-\mathrm{R} 180 \mathrm{X}_{3}$ chimeras at saturating agonist concentrations were comparable, whereas the maximal P2X $\mathrm{X}_{2 \mathrm{a}} / \mathrm{N} 60-\mathrm{F} 301 \mathrm{X}_{3}$, and $\mathrm{P} 2 \mathrm{X}_{2 \mathrm{~b}} / \mathrm{V} 60-\mathrm{F}_{301 \mathrm{X}_{3}}$ currents were $50-60 \%$ of that observed in parental receptors.

sponse curves for these receptors, cells were stimulated with a single agonist concentration, and curves were generated from five to eight experiments per dose. The threshold ATP concentration for activation of $\mathrm{P} 2 \mathrm{X}_{2 \mathrm{a}} / \mathrm{V} 60-\mathrm{F} 301 \mathrm{X}_{3}$ and $\mathrm{P} 2 \mathrm{X}_{2 \mathrm{~b}} / \mathrm{V} 60-\mathrm{F} 301 \mathrm{X}_{3}$ chi- meras was $\sim 5 \mathrm{nM}$, and the estimated $\mathrm{EC}_{50}$ value was $50 \mathrm{~nm}$. Chimeric receptor also responded to other agonists in a concentration-dependent manner, with $\mathrm{EC}_{50}$ values ranging from 19 to $267 \mathrm{~nm}$ and with comparable peak amplitudes. Figure $1, B$ and $C$, illustrates the combined results for both receptors. However, the threshold for activation of $\mathrm{P}_{2 \mathrm{X}} \mathrm{a}_{\mathrm{a}} / \mathrm{V} 60-\mathrm{R} 180 \mathrm{X}_{3}$ chimera by ATP was $10-20 \mathrm{nM}$, and the estimated $\mathrm{EC}_{50}$ values for ATP and other agonists were between those at $\mathrm{P} 2 \mathrm{X}_{3} \mathrm{R}$ and $\mathrm{P} 2 \mathrm{X}_{2 \mathrm{a}} \mathrm{R}$ (Fig. $1 B, C$ ). These results indicate that the V60-F301 ectodomain sequence of $\mathrm{P} 2 \mathrm{X}_{3} \mathrm{R}$ accounts for the ligand-selective profile of $\mathrm{P} 2 \mathrm{X}_{3} \mathrm{R}$ and that both $\mathrm{N}$ and $\mathrm{C}$ halves of this sequence contribute to the efficacy of agonists.

\section{Patterns of signaling by wild-type and chimeric P2XRs}

The time course of $\mathrm{P} 2 \mathrm{X}_{3} \mathrm{R}$ current was dependent on agonist concentration and duration of stimuli. In a concentration range of 10-100 nM, the sustained ATP application usually generated a biphasic response. As shown in Figure $2 A$, during repetitive stimulation with $10 \mathrm{~nm} \mathrm{ATP} \mathrm{(60} \mathrm{or} 30 \mathrm{sec}$ followed by $30 \mathrm{sec}$ washing period), a biphasic response was present only during the first ATP pulse. Removal of ATP was followed by a rapid and monoexponential decline in current. The decay of $\mathrm{P} 2 \mathrm{X}_{3} \mathrm{R}$ current evoked by removal of $10 \mathrm{nM}$ ATP was well fitted by a single exponential function, with $\tau_{\text {off }}$ of $506 \pm 18 \mathrm{msec}(n=12)$. Both the decline in current after removal of agonist and the rise in current after restimulation of cells indicate that $\tau_{\text {off }}$ reflects $\mathrm{P} 2 \mathrm{X}_{3} \mathrm{R}$ deactivation. However, there was a gradual decrease in peak response during repetitive stimulation with $10 \mathrm{~nm}$ ATP, indicating a slow desensitization of receptor (Fig. $2 A$ ). At higher (100 nM to $5 \mu \mathrm{M}$ ) concentrations, only monophasic responses were observed, and these responses rapidly declined (Fig. $2 B, C$ ). Restimulation of cells resulted in currents, the peak amplitude of which were comparable with the plateau current induced by previous ATP pulse, indicating that the decrease in current during agonist stimulation reflects desensitization of receptors. At $5 \mu \mathrm{M}$ (Fig. 2D) and higher ATP concentrations, $\mathrm{P} 2 \mathrm{X}_{3} \mathrm{R}$ current completely desensitized within $10 \mathrm{sec}$. Consistent with literature (Lewis et al., 1995), in cells stimulated with $0.1-10 \mu \mathrm{M}$ ATP, the $\mathrm{P}_{2} \mathrm{X}_{3} \mathrm{R}$ desensitization profile was best described by the sum of two exponentials. Both fast $\left(\tau_{\text {des } 1}\right)$ and slow $\left(\tau_{\text {des } 2}\right)$ desensitization time constants decreased with increase in ATP concentration (Fig. 2E). When stimulated with $1 \mu \mathrm{M}$ ATP, the mean value of $\tau_{\text {des } 1}$ was $0.55 \pm$ $0.04 \mathrm{sec}$, and the mean value of $\tau_{\text {des } 2}$ was $5.0 \pm 0.45 \mathrm{sec}$; both fast and slow desensitization processes almost equally contributed to the decay in current (Table 1).

$\mathrm{P} 2 \mathrm{X}_{2 \mathrm{a}} \mathrm{R}$ and $\mathrm{P} 2 \mathrm{X}_{2 \mathrm{~b}} \mathrm{R}$ also responded with biphasic nondesensitizing currents when stimulated with $100 \mathrm{~nm}$ to $5 \mu \mathrm{M}$ ATP, and at higher ATP concentrations, these receptors usually responded with monophasic currents. In accordance with previously published data (Brandle et al., 1997; Simon et al., 1997; Koshimizu et al., 1998), $\mathrm{P} 2 \mathrm{X}_{2 \mathrm{a}} \mathrm{R}$ and $\mathrm{P} 2 \mathrm{X}_{2 \mathrm{~b}} \mathrm{R}$ desensitized with different rates and to different plateau levels (Table 1). In response to stimulation with saturating $(100 \mu \mathrm{M})$ ATP concentrations for $60 \mathrm{sec}$, $\mathrm{P} 2 \mathrm{X}_{2 \mathrm{a}} \mathrm{R}$ partially desensitized with slow rates, whereas $\mathrm{P} 2 \mathrm{X}_{2 \mathrm{~b}} \mathrm{R}$ desensitized to higher degree and more rapidly (Fig. 3A). The desensitization decay for both receptors was usually described with the sum of two exponentials; $\tau_{\mathrm{des} 1}$ contributed to the desensitization decay of $\mathrm{P} 2 \mathrm{X}_{2 \mathrm{a}} \mathrm{R}$ and $\mathrm{P} 2 \mathrm{X}_{2 \mathrm{~b}} \mathrm{R}$ on average by 25 and $50 \%$, respectively (Table 1$)$. Both currents declined rapidly after removal of ATP. The estimated $\tau_{\text {off }}$ values after $60 \mathrm{sec}$ stimulation with $10 \mu \mathrm{M}$ ATP (a time sufficient to reach the equilibrium in current) were $294 \pm 33 \mathrm{msec}(n=15)$ and $231 \pm 19 \mathrm{msec}(n=9)$ for $\mathrm{P} 2 \mathrm{X}_{2 \mathrm{a}} \mathrm{R}$ and $\mathrm{P} 2 \mathrm{X}_{2 \mathrm{~b}} \mathrm{R}$, respectively. These values are in the 
A

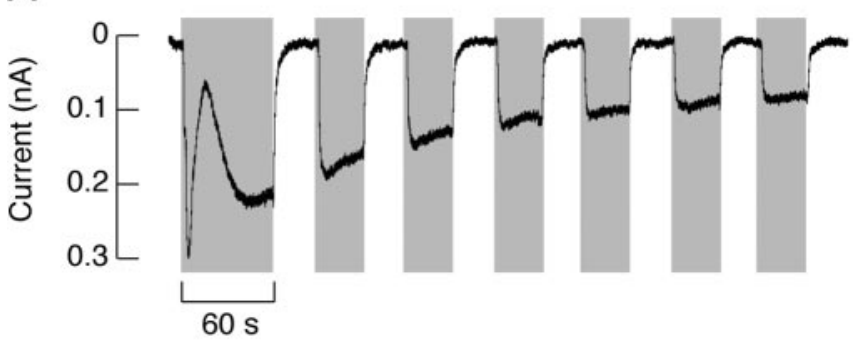

B

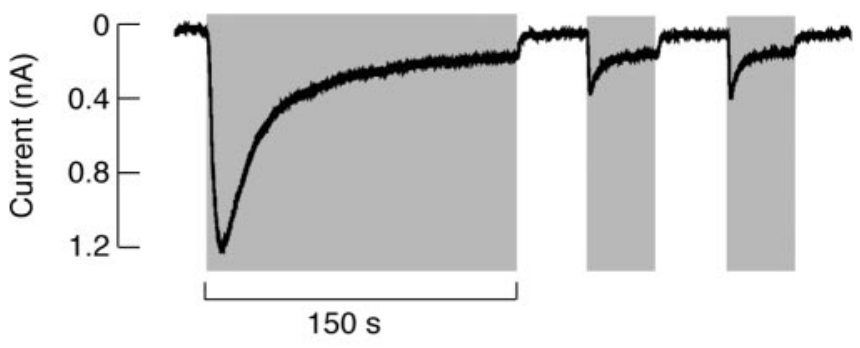

C

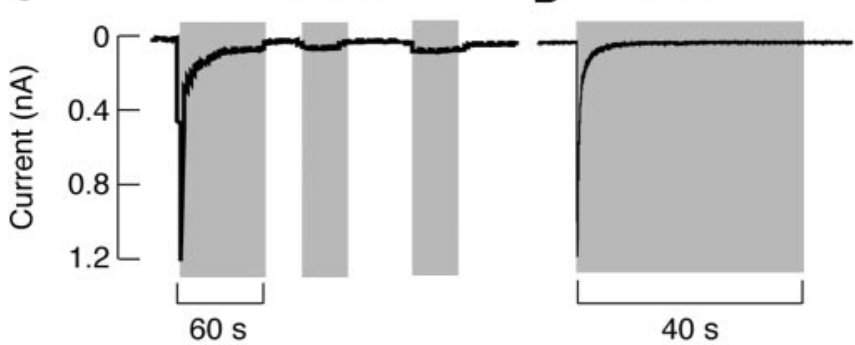

$\mathrm{E}$

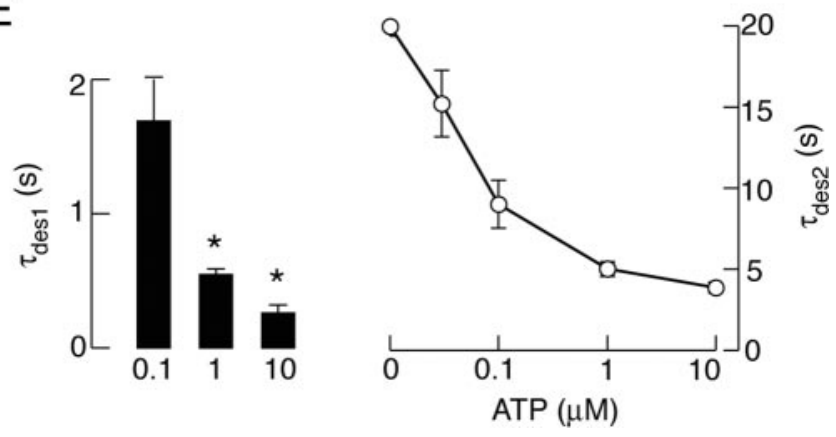

Figure 2. Concentration-dependent effects of ATP on $P 2 X_{3}$ R current activation, desensitization, and deactivation. $A-C$, Repetitive stimulation of cells with $10 \mathrm{~nm}(A), 100 \mathrm{~nm}(B)$, and $1 \mu \mathrm{M}$ (C) ATP.D, Typical trace of rapidly desensitizing currents in response to $5 \mu \mathrm{m}$ ATP. In this and the following figures, gray areas indicate the duration of agonist application. $E$, Inverse correlation between ATP concentrations and $\tau_{\text {des } 1}$ (left) and $\tau_{\text {des } 2}$ (right) values. Asterisks indicate significant differences between 0.1 and 1 or $10 \mu \mathrm{M}$. Values shown are mean $\pm \mathrm{SEM}$, with $n$ between 4 and 16 per dose.

range observed by others (Li et al., 1997), but in our experimental conditions, they should be considered with reservation, because the solution exchange time of perfusion system was too slow to accurately measure deactivation of $\mathrm{P}_{2} \mathrm{X}_{2} \mathrm{Rs}$ (see Materials and Methods).

At lower ATP concentrations, chimeric receptors also consistently responded with a biphasic pattern of signaling, and at higher concentrations, monophasic desensitizing responses were observed. $\mathrm{P} 2 \mathrm{X}_{2 \mathrm{a}} / \mathrm{V} 60-\mathrm{R} 180 \mathrm{X}_{3}$ desensitized in a manner compa- rable with that observed in cells expressing parental $\mathrm{P} 2 \mathrm{X}_{2 \mathrm{a}} \mathrm{R}$. Figure $3 B$ illustrates a typical time course of current in response to 1 $\mu \mathrm{M}$ ATP. The desensitization decay for this receptor was also best fitted with the sum of two exponentials, and the slow desensitizing component was dominant (Table 1). After a $60 \mathrm{sec}$ application of $1 \mu \mathrm{M}$ ATP, when the equilibrium in current was usually reached, there was a relatively rapid return to basal level, indicating that, for this receptor, the decay in current after removal of ATP reflected the deactivation of channels. In $72 \%$ of cells, the ATP-induced current declined monoexponentially with a $\tau_{\text {off }}$ value of $0.87 \pm 0.17 \mathrm{sec}$. In residual cells, a biexponential function was the best fit for the decay of current and the second component was in the range of 5-8 sec and contributed to the decay of current by $<20 \%$.

Similar to parental $\mathrm{P} 2 \mathrm{X}_{2 \mathrm{a}} \mathrm{R}$ and $\mathrm{P} 2 \mathrm{X}_{2 \mathrm{~b}} \mathrm{R}$, chimeric $\mathrm{P} 2 \mathrm{X}_{2 \mathrm{a}} / \mathrm{V} 60$ $\mathrm{F} 301 \mathrm{X}_{3}$ and $\mathrm{P} 2 \mathrm{X}_{2 \mathrm{~b}} / \mathrm{V} 60-\mathrm{F}_{301 \mathrm{X}_{3}}$ receptors also desensitized with different rates (Fig. $3 C$ ). $\mathrm{P} 2 \mathrm{X}_{2 \mathrm{~b}} / \mathrm{V} 60-\mathrm{F} 301 \mathrm{X}_{3}$ desensitized rapidly and monoexponentially in response to $1 \mu \mathrm{M}$ ATP, and the desensitization of the $\mathrm{P}_{2} \mathrm{X}_{2 \mathrm{a}} / \mathrm{V} 60-\mathrm{F} 301 \mathrm{X}_{3}$ chimera was best described by the sum of two exponentials, and the slow component was dominant (Table 1). However, two chimeric channels differed from parental receptors with respect to the plateau response and the decay of response after removal of agonist. Whereas the $\mathrm{P} 2 \mathrm{X}_{2 \mathrm{a}} \mathrm{R}$ and $\mathrm{P} 2 \mathrm{X}_{2 \mathrm{~b}} \mathrm{R}$ desensitization current reached plateau after 60-90 sec of agonist application (Table 1), P2X $2 \mathrm{a} / \mathrm{V} 60-\mathrm{F} 301 \mathrm{X}_{3}$ and $\mathrm{P} 2 \mathrm{X}_{2 \mathrm{~b}} / \mathrm{V} 60-\mathrm{F} 301 \mathrm{X}_{3}$ currents declined to basal level during the sustained agonist stimulation. Practically, the $\mathrm{P} 2 \mathrm{X}_{2 \mathrm{a}} / \mathrm{V} 60$ $\mathrm{F}_{301 \mathrm{X}_{3}}$ current declined to zero during 2 min exposure to $10 \mu \mathrm{M}$ $\mathrm{ATP}$, and $\mathrm{P} 2 \mathrm{X}_{2 \mathrm{~b}} / \mathrm{V} 60-\mathrm{F} 301 \mathrm{X}_{3}$ reached zero level within $30 \mathrm{sec}$ of stimulation with $10 \mu \mathrm{M}$ ATP. Furthermore, no obvious changes in the profile of currents were observed after removal of ATP in these chimera-expressing cells (Fig. 3C). Thus, although the ATP potency for $\mathrm{P} 2 \mathrm{X}_{3} \mathrm{R}$ and $\mathrm{P} 2 \mathrm{X}_{2 \mathrm{a}} / \mathrm{V} 60-\mathrm{F} 301 \mathrm{X}_{3}$ and $\mathrm{P} 2 \mathrm{X}_{2 \mathrm{~b}} / \mathrm{V} 60$ $\mathrm{F}_{301 \mathrm{X}_{3}}$ chimeras was comparable, there was $>65$-fold difference in the rates of current decay between parental and chimeric receptors after agonist removal, indicating that the transfer of the V60-F301 sequence in the backbone of P2X $\mathrm{X}_{2}$ Rs affects the deactivation properties of receptors.

\section{Agonist-dependent gating-deactivation coupling}

The receptor specificity of current decays after agonist withdrawal was practically independent of duration of ATP pulse. Figure $4 A$ illustrates that $\mathrm{P} 2 \mathrm{X}_{3} \mathrm{R}$ current declined rapidly after 10 nM ATP application of different duration. The other parental receptor also deactivated rapidly and independently of duration of ATP pulse (Fig. $4 \mathrm{~B}$ ). Similarly, $\mathrm{P}_{2 \mathrm{X}} \mathrm{a}_{\mathrm{a}} / \mathrm{V} 60-\mathrm{R} 180 \mathrm{X}_{3}$ currents declined with comparable rates after ATP application of variable duration (data not shown). The delay in $\mathrm{P}_{2 \mathrm{X}} \mathrm{a} / \mathrm{V} 60-\mathrm{F} 301 \mathrm{X}_{3}$ (Fig. $4 C$ ) and $\mathrm{P}_{2} \mathrm{X}_{2 \mathrm{~b}} / \mathrm{V} 60-\mathrm{F} 301 \mathrm{X}_{3}(D)$ current decays was also observed after shorter ATP application.

A more detailed analysis of the kinetics of $\mathrm{P} 2 \mathrm{X}_{2 \mathrm{a}} / \mathrm{V} 60-\mathrm{F} 301 \mathrm{X}_{3}$ and $\mathrm{P} 2 \mathrm{X}_{2 \mathrm{~b}} / \mathrm{V} 60-\mathrm{F} 301 \mathrm{X}_{3}$ current decays after a prolonged $(60 \mathrm{sec})$ and brief $(2 \mathrm{sec})$ stimulation with $1 \mu \mathrm{M}$ ATP is shown in Figure 5. The derived time constants (shown below traces) from fitting curves (shown by dotted lines) reflect the rates of receptor desensitization (left panels) and the rates of current decay after washout of ATP (right panels). The similarity in $\tau_{\text {des }}$ and $\tau_{\text {off }}$ values for both chimeras is consistent with a hypothesis that, once activated, $\mathrm{P}_{2 \mathrm{X}} / \mathrm{a}$-V60-F301X $\mathrm{X}_{3}$ and $\mathrm{P} 2 \mathrm{X}_{2 \mathrm{~b}} / \mathrm{V} 60-\mathrm{F} 301 \mathrm{X}_{3}$ receptors undergo desensitization rather than deactivation. Because the desensitization of $\mathrm{P} 2 \mathrm{X}_{2 \mathrm{~b}} / \mathrm{V} 60-\mathrm{F}_{0} 01 \mathrm{X}_{3}$ current was very rapid and was practically impossible to fit the deactivation currents recorded after sustained agonist application, in additional studies, we used the 
Table 1. Characterization of ATP-induced desensitization decays in parental and chimeric receptors

\begin{tabular}{|c|c|c|c|c|c|c|}
\hline Receptor & ATP $(\mu \mathrm{M})$ & $\tau_{\text {des } 1}(\mathrm{sec})$ & $\tau_{\text {des } 1}(\%)$ & $\tau_{\text {des } 2}(\mathrm{sec})$ & Des- $\%$ & $n$ \\
\hline $\mathrm{P} 2 \mathrm{X}_{3}$ & 1 & $0.55 \pm 0.04$ & 59.0 & $5.00 \pm 0.45$ & & 16 \\
\hline$P 2 X_{2 b}$ & 50 & $6.1 \pm 0.8$ & 50.2 & $29.8 \pm 8.4$ & $28.3 \pm 5.3$ & 20 \\
\hline $\mathrm{P} 2 \mathrm{X}_{2 \mathrm{~b}} / \mathrm{V} 60-\mathrm{F} 301 \mathrm{X}_{3}$ & 1 & $4.3 \pm 0.3$ & 100 & & $8.4 \pm 1.6$ & 20 \\
\hline $\mathrm{P} 2 \mathrm{X}_{2 \mathrm{a}}$ & 50 & $3.1 \pm 0.6$ & 25.3 & $34.5 \pm 3.5$ & $73.5 \pm 3.3$ & 24 \\
\hline $\mathrm{P} 2 \mathrm{X}_{2 \mathrm{a}} / \mathrm{V} 60-\mathrm{F} 301 \mathrm{X}_{3}$ & 1 & $5.9 \pm 0.7$ & 18.5 & $35.5 \pm 5.7$ & $33.6 \pm 3.9$ & 10 \\
\hline $\mathrm{P} 2 \mathrm{X}_{2 \mathrm{a}} / \mathrm{V} 60-\mathrm{R} 180 \mathrm{X}_{3}$ & 5 & $2.9 \pm 0.9$ & 22.3 & $31.4 \pm 3.4$ & $63.3 \pm 4.9$ & 17 \\
\hline
\end{tabular}

The first $\left(\tau_{\text {des } 1}\right)$ and second $\left(\tau_{\text {des } 2}\right)$ desensitization time constants were derived from a double exponential fit of the current decay in response to stimulation with saturating ATP concentrations for 1 min. The $\tau_{\text {des } 1}(\%)$ represents the relative amplitude of the first exponential. Des-\% represents the percentage of the current present after 60 sec of stimulation related to the peak current, and for $P 2 X_{2 a} R, P 2 X_{2 b} R$, and $P 2 X_{2 a} / V 60-R 180 X_{3}$, this value reflects the equilibrium plateau. Data shown are means $\pm \mathrm{SEM}$, and $n$ indicates the number of records.

A

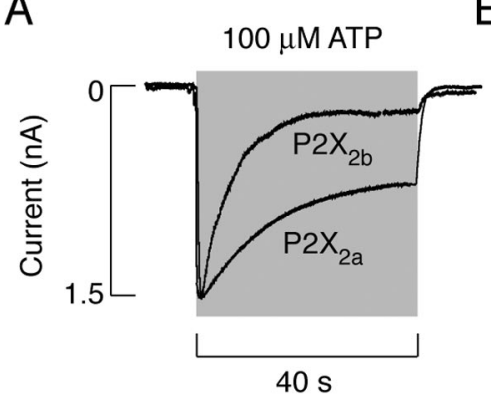

B

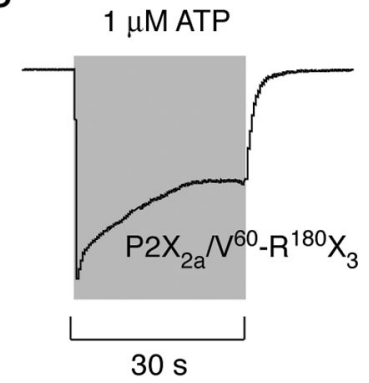

C

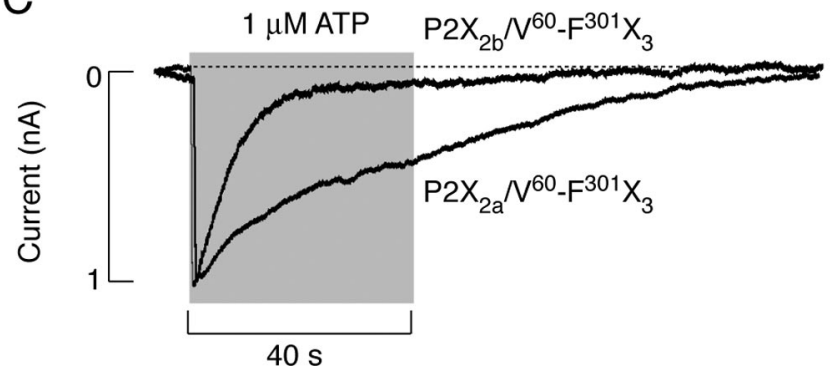

Figure 3. Patterns of current signaling by $P 2 X_{2} R$ and chimeric receptors. $A$, Typical traces of $P 2 X_{2 b} R$ (top trace) and $P 2 X_{2 a} R$ (bottom trace) currents induced by 40 sec application of $100 \mu \mathrm{m}$ ATP. B, Current signaling by P2X $\mathrm{X}_{2 \mathrm{a}} / \mathrm{N} 60-\mathrm{R} 180 \mathrm{X}_{3}$ chimera induced by 30 sec application of $1 \mu \mathrm{M}$ ATP. C, Superimposed responses of $\mathrm{P} 2 \mathrm{X}_{2 \mathrm{a}} / \mathrm{N} 60-\mathrm{F} 301 \mathrm{X}_{3}$ and $\mathrm{P} 2 \mathrm{X}_{2 \mathrm{~b}} / \mathrm{N} 60-\mathrm{F} 301 \mathrm{X}_{3}$ chimeras to 40 sec application of $1 \mu \mathrm{M}$ ATP.

slow desensitizing $\mathrm{P}_{2 \mathrm{X}} / \mathrm{V} 60-\mathrm{F} 301 \mathrm{X}_{3}$ and $\mathrm{P} 2 \mathrm{X}_{2 \mathrm{a}} / \mathrm{V} 60-\mathrm{R} 180 \mathrm{X}_{3}$ chimeras as receptor models to study the deactivation and resensitization properties of channels.

The dose-dependent studies revealed relatively rapid decays in $\mathrm{P} 2 \mathrm{X}_{2 \mathrm{a}} / \mathrm{V} 60-\mathrm{R}_{180 \mathrm{X}_{3}}$ current, but not $\mathrm{P} 2 \mathrm{X}_{2 \mathrm{a}} / \mathrm{V} 60-\mathrm{F} 301 \mathrm{X}_{3}$ current, in all of the concentrations of ATP tested (Fig. 6A,C). Basically, there was $\sim 30$-fold difference in $\tau_{\text {off }}$ values for two chimeric receptors, reinforcing the conclusion that the $\mathrm{C}$ half of ectodomain is critical for changes in deactivation properties of the $\mathrm{P} 2 \mathrm{X}_{2 \mathrm{a}} / \mathrm{V} 60-\mathrm{F}_{301 \mathrm{X}_{3}}$ chimera. Furthermore, for both chimeras, there was an increase in $\tau_{\text {off }}$ values with increase in ATP concentrations (Fig. 6B,D).

To test the agonist specificity of decays in currents after their washout, in additional experiments, cells expressing $\mathrm{P} 2 \mathrm{X}_{2 \mathrm{a}} / \mathrm{V} 60$ $\mathrm{R}_{180 \mathrm{X}_{3}}$ and $\mathrm{P} 2 \mathrm{X}_{2 \mathrm{a}} / \mathrm{V} 60-\mathrm{F} 301 \mathrm{X}_{3}$ chimeras were stimulated with different agonists for a brief period. Figure $7 A$ illustrates the ligand specificity in the pattern of $\mathrm{P} 2 \mathrm{X}_{2 \mathrm{a}} / \mathrm{V} 60-\mathrm{R} 180 \mathrm{X}_{3}$ current decays after $5 \mathrm{sec}$ agonist stimulation. In all of the cases, currents declined to basal level relatively rapidly. In addition, there were ligand-specific differences in the rates of $\mathrm{P} 2 \mathrm{X}_{2 \mathrm{a}} / \mathrm{V} 60-\mathrm{R} 180 \mathrm{X}_{3}$ current decay after washout of agonists, in the following order (from slow to fast declining): 2MeSATP $>$ ATP $>$ BzATP $>\alpha \beta$ meATP $>$ ATP $\gamma$ S. The decay of $\mathrm{P}_{2} \mathrm{X}_{2 \mathrm{a}} / \mathrm{V} 60-\mathrm{F} 301 \mathrm{X}_{3}$ current after application of agonists for $2 \mathrm{sec}$ was also ligand specific and occurred in the same rank order as in $\mathrm{P}_{2 \mathrm{X}} \mathrm{a} / \mathrm{V} 60-\mathrm{R}_{180 \mathrm{X}_{3}-}$ expressing cells (Fig. $7 B$ ). For both chimeras, the decay of currents induced by withdrawal of $2 \mathrm{MeSATP}$ and ATP was best fitted with double exponential functions, whereas monoexponential functions were best fits for decay of currents after washout of agonists with lower potency. As in dose-response studies with $\mathrm{ATP}$, the rates of $\mathrm{P} 2 \mathrm{X}_{2 \mathrm{a}} / \mathrm{V} 60-\mathrm{F} 301 \mathrm{X}_{3}$ current decays were always 4 - to 24 -fold slower than for $\mathrm{P}_{2 \mathrm{X}_{2 \mathrm{a}}} / \mathrm{V} 60-\mathrm{R} 180 \mathrm{X}_{3}$ current. Because both $\mathrm{P} 2 \mathrm{X}_{2 \mathrm{a}} / \mathrm{V} 60-\mathrm{R} 180 \mathrm{X}_{3}$ and $\mathrm{P} 2 \mathrm{X}_{2 \mathrm{a}} / \mathrm{V} 60-\mathrm{F} 301 \mathrm{X}_{3}$ chimeras exhibited similar rank orders in their $\mathrm{EC}_{50}$ values for agonists (Fig. $1 C$ ), these results indicate that the rate of current decay after agonist washout was influenced by ligand potency, but in a receptor-specific manner.

The finding that decays of $\mathrm{P} 2 \mathrm{X}_{2 \mathrm{a}} / \mathrm{V} 60-\mathrm{F} 301 \mathrm{X}_{3}$ currents are considerably faster after removal of $\alpha \beta$-meATP and ATP $\gamma \mathrm{S}$ compared with high-affinity agonists (Fig. $7 B$ ), prompted us to further examine the effects of these two agonists on current desensitization and deactivation. As shown in Figure $8 A$, the $\mathrm{P}_{2} \mathrm{X}_{2 \mathrm{a}} /$ V60-F301X $\mathrm{X}_{3}$ chimera desensitized slowly during sustained stimulation with $1 \mu \mathrm{M}$ ATP $\gamma \mathrm{S}$, and the decay could not be fitted with an exponential function. However, the washout of this agonist induced a decline in current with a time constant of $5 \mathrm{sec}$ (Fig. $8 \mathrm{~A}$ ), indicating that the majority of receptors deactivate when ATP $\gamma S$ was removed (see also Fig. 10C). Furthermore, $0.1 \mu \mathrm{M}$ $\alpha \beta$-meATP triggered a moderate desensitization of chimeric receptor, which could be fitted by a monoexponential function with plateau, and removal of agonist near the equilibrium induced an additional decline in current (Fig. $8 \mathrm{~B}$ ). These results clearly indicate that deactivation also participates in the decay of $\mathrm{P}_{2 \mathrm{X}} / \mathrm{a} 60-\mathrm{F}_{201 \mathrm{X}_{3}}$ current after washout of lower affinity agonists.

We also correlated the $\mathrm{EC}_{50}$ values for agonists with the corresponding $\tau_{\text {off }}$ and $\tau_{\text {des }}$ values for the $\mathrm{P}_{2} \mathrm{X}_{2 \mathrm{a}} / \mathrm{V} 60-\mathrm{F} 301 \mathrm{X}_{3}$ chimera. The desensitization rates were calculated during the $30-60$ sec stimulation, and $\tau_{\text {off }}$ values were derived from experiments with 2 sec stimulation with saturating concentrations of agonists. As shown in Figure 8, there was an inverse linear-log relationship between $\mathrm{EC}_{50}$ values and the corresponding $\tau_{\text {off }}$ values (Fig. $8 C$ ), in contrast to a linear relationship between $\mathrm{EC}_{50}$ values and slow dominant $\tau_{\text {des }}$ values for these agonists $(D)$. The $\tau_{\text {off }}$ values also inversely correlated with the $\tau_{\text {des }}$ values $(r=0.98$ for the loglinear correlation), further indicating that the decay in $\mathrm{P}_{2} \mathrm{X}_{2 \mathrm{a}}$ l V60-F301X ${ }_{3}$ current after washout of high-potency agonists predominantly reflects continuous desensitization of receptor, whereas the decay in current after withdrawal of low-potency agonists predominantly reflects slow deactivation of chimera.

Finally, we compared the $\mathrm{EC}_{50}$ values for ATP and ATP $\gamma \mathrm{S}$ with deactivation kinetics of receptors to clarify whether the chimerization-induced shift in $\mathrm{EC}_{50}$ values for these agonists parallels changes in the rate of receptor deactivation. To reduce the 
A

$\mathrm{P} \mathrm{X}_{3}$

$10 \mathrm{nM}$ ATP

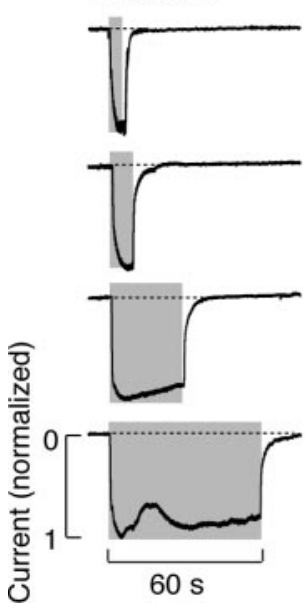

B

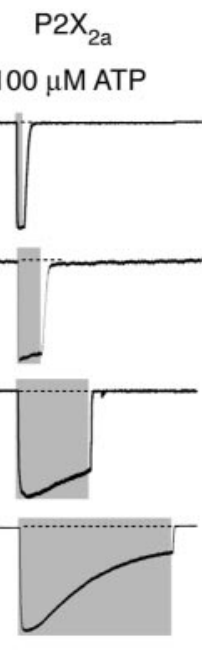

C

$\mathrm{P} 2 \mathrm{X}_{2 \mathrm{a}} / \mathrm{N}^{60}-\mathrm{F}^{301} \mathrm{X}_{3}$

$10 \mu \mathrm{M}$ ATP
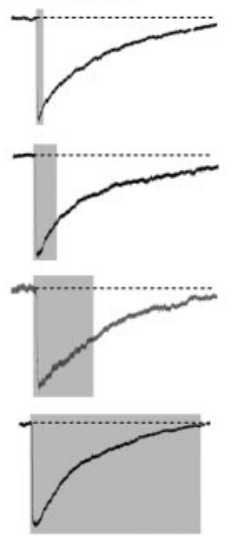

D

P2X ${ }_{20} \mathrm{~N}^{\mathrm{60}-\mathrm{F}^{301} \mathrm{X}_{3}}$

$10 \mu \mathrm{M}$ ATP

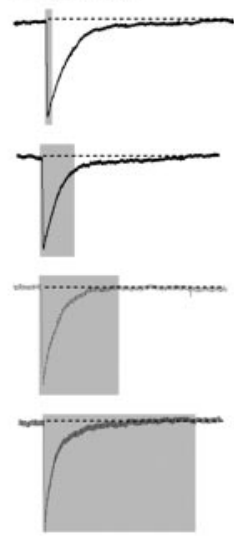

Figure 4. Independence of decay of currents after agonist withdrawal of duration of stimuli. Typical patterns of $P 2 X_{3}(A), P 2 X_{2 a}$ $(B), \mathrm{P} 2 \mathrm{X}_{2 \mathrm{a}} / \mathrm{V} 60-\mathrm{F}_{301 \mathrm{X}_{3}}\left(\mathrm{C}\right.$, and $\mathrm{P} 2 \mathrm{X}_{2 \mathrm{~b}} / \mathrm{N} 60-\mathrm{F}_{0} 01 \mathrm{X}_{3}(D)$ current decays in response to ATP pulses of variable duration.

$\mathrm{F}_{301 \mathrm{X}_{3}}$ chimera was 5.8 -fold slower than of the wild-type channel. Furthermore, $\mathrm{P}_{2 \mathrm{X}}$ /V60-R180X $\mathrm{X}_{3}$ chimera exhibited a significantly higher $\mathrm{EC}_{50}$ value for ATP $\gamma \mathrm{S}$, but deactivated with rates comparable with that observed in $\mathrm{P}_{2} \mathrm{X}_{3} \mathrm{R}$-expressing cells (Table 2). These findings indicate that the P2XR-specific transition from open to closed state, but not the removal of agonist from the ligand-binding domain, represents the rate-limiting step for receptor deactivation.

\section{Recovery from desensitization}

To estimate the recovery time for parental and chimeric receptors, cells were stimulated repetitively with 30-60 sec of ATP or ATP $\gamma \mathrm{S}$ pulses, with a progressive increase in the interpulse intervals (Fig. 9A,C). The ATP pulses were sufficient to almost completely desensitize $\mathrm{P} 2 \mathrm{X}_{2 \mathrm{~b}} \mathrm{R}$ and $\mathrm{P} 2 \mathrm{X}_{3} \mathrm{R}$, whereas the extent of $\mathrm{P} 2 \mathrm{X}_{2 \mathrm{a}} \mathrm{R}$ desensitization at plateau was $\sim 25 \%$ (Table 1 ). The recovery of $\mathrm{P} 2 \mathrm{X}_{2 \mathrm{~b}} \mathrm{R}$ from desensitization

A

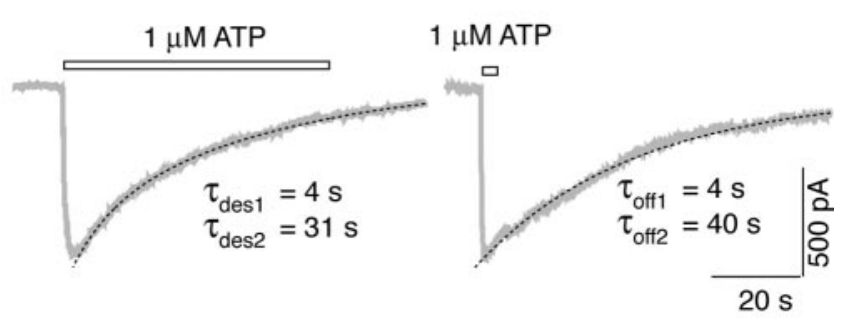

B
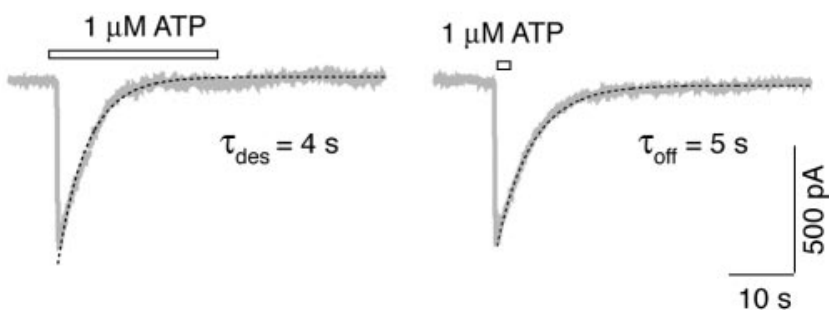

Figure 5. Comparison of decay rates of $\mathrm{P} 2 \mathrm{X}_{2 \mathrm{a}} / \mathrm{N} 60-\mathrm{F}_{301 \mathrm{X}_{3}}(A)$ and $\mathrm{P} 2 \mathrm{X}_{2 \mathrm{~b}} / \mathrm{N} 60-\mathrm{F} 301 \mathrm{X}_{3}(B)$ currents during the long-term (left traces) and short-term (right traces) stimulation with $1 \mu \mathrm{M}$ ATP. Gray traces represent experimental records, and black dotted lines illustrate fitting curves (see Materials and Methods). The decay time constants are shown below traces. Bars above traces indicate the duration of ATP application.

participation of desensitization to the decay of currents, the washout of agonists was initiated when the plateau in current was reached or application of nondesensitizing agonist concentrations was used. As shown in Table 2, a significant increase in $\mathrm{EC}_{50}$ value for $\mathrm{ATP}$ at $\mathrm{P} 2 \mathrm{X}_{2 \mathrm{a}} / \mathrm{V} 60-\mathrm{R}_{180 \mathrm{X}_{3}}$ chimera compared with parental $\mathrm{P} 2 \mathrm{X}_{3} \mathrm{R}$ was not accompanied with a decrease in $\tau_{\text {off }}$. Because the equilibrium in decay of $\mathrm{P}_{2} \mathrm{X}_{2 \mathrm{a}} / \mathrm{V} 60-\mathrm{F} 301 \mathrm{X}_{3}$ chimera could not be reached during sustained ATP stimulation, it was incorrect to compare $\mathrm{EC}_{50}$ and $\tau_{\text {off }}$ values at $\mathrm{P} 2 \mathrm{X}_{3} \mathrm{R}$ and the $\mathrm{P}_{2 \mathrm{X}} / \mathrm{V}$ /V0-F301X $\mathrm{X}_{3}$ chimera. However, this was not the case with ATP $\gamma \mathrm{S}$, a low-potency agonist for three receptors. Both $\mathrm{P}_{2} \mathrm{X}_{3} \mathrm{R}$ and $\mathrm{P} 2 \mathrm{X}_{2 \mathrm{a}} / \mathrm{V} 60-\mathrm{F} 301 \mathrm{X}_{3}$ chimera exhibited highly comparable $\mathrm{EC}_{50}$ values for this agonist, but deactivation of $\mathrm{P} 2 \mathrm{X}_{2 \mathrm{a}} / \mathrm{V} 60$ - occurred monoexponentially, with a time constant $\left(\tau_{\text {rec }}\right)$ of $55 \mathrm{sec}$ (Fig. $9 B$ ), and the desensitized portion of $\mathrm{P} 2 \mathrm{X}_{2 \mathrm{a}} \mathrm{R}$ current recovered with a similar time constant (data not shown). However, the $\mathrm{P} 2 \mathrm{X}_{3} \mathrm{R}$ recovered with a $\tau_{\text {rec }}$ value of $141 \mathrm{sec}$ (Fig. 9D).

Repetitive stimulation of $\mathrm{P}_{2 \mathrm{X}} / \mathrm{V} / \mathrm{V} 60-\mathrm{F} 301 \mathrm{X}_{3}$ chimera with 30 sec pulses of $1 \mu \mathrm{M}$ ATP led to a progressive decrease in response. As shown in Figure $10 \mathrm{~A}$, the current did not decline to basal level during the first three pulses, indicating continuous desensitization of receptors between ATP stimuli. Receptors showed only a partial recovery of response with increase in the interpulse periods (Fig. 10A). The full recovery of response was never reached within up to $40 \mathrm{~min}$ of washing period. The involvement of desensitization in the decay of responses to short stimulation with high ATP concentration was also reexamined. When stimulated with $10 \mu \mathrm{M}$ ATP for $2 \mathrm{sec}$, followed by a $9.5 \mathrm{~min}$ washing period, the subsequent ATP pulse generated a signal, of which the amplitude was only $44 \%$ of the first peak response (Fig. $10 \mathrm{~B}$ ). When the washing period was decreased to $1 \mathrm{~min}$, the recovery of response was $21 \%$. These data confirmed that the main component in decay of $\mathrm{P} 2 \mathrm{X}_{2 \mathrm{a}} / \mathrm{V} 60-\mathrm{F} 301 \mathrm{X}_{3}$ currents after washout of ATP was attributable to desensitization of channels.

In contrast to ATP, a prolonged stimulation with $1 \mu \mathrm{MATP} \gamma \mathrm{S}$ only partially desensitized the $\mathrm{P}_{2} \mathrm{X}_{2 \mathrm{a}} / \mathrm{V} 60-\mathrm{F} 301 \mathrm{X}_{3}$ chimera (Fig. $10 C)$. Furthermore, removal of agonist was followed by a relatively rapid decay in current, and there was almost complete recovery of the nondesensitizing component of $\mathrm{P} 2 \mathrm{X}_{2 \mathrm{a}} / \mathrm{V} 60-\mathrm{F} 301 \mathrm{X}_{3}$ current when the interpulse interval was $>30 \mathrm{sec}$. These data confirmed that the main component in decay of $\mathrm{P} 2 \mathrm{X}_{2 \mathrm{a}} / \mathrm{V} 60$ $\mathrm{F}_{301 X_{3}}$ currents after washout of ATP $\gamma \mathrm{S}$ was attributable to deactivation of receptors. However, there was no recovery of receptors from desensitization during tens of minutes after washout of ATP $\gamma \mathrm{S}$, indicating that not only the stability of gating state but also the stability of desensitized conformation state is enhanced in the $\mathrm{P} 2 \mathrm{X}_{2 \mathrm{a}} / \mathrm{V} 60-\mathrm{F} 301 \mathrm{X}_{3}$ chimera.

The recovery from the desensitization state of the $\mathrm{P} 2 \mathrm{X}_{2 \mathrm{a}} / \mathrm{V} 60$ $\mathrm{R} 180 \mathrm{X}_{3}$ chimera, which deactivated more rapidly than the $\mathrm{P} 2 \mathrm{X}_{2 \mathrm{a}}$ / $\mathrm{V} 60-\mathrm{F}_{301 \mathrm{X}_{3}}$ chimera, was also dramatically extended. Figure $10 \mathrm{D}$ illustrates that recovery of a nondesensitized component of $\mathrm{P}_{2 \mathrm{X}} \mathrm{a}_{\mathrm{a}} / \mathrm{V} 60-\mathrm{R} 180 \mathrm{X}_{3}$ current was fast, whereas the interpulse in- 
A

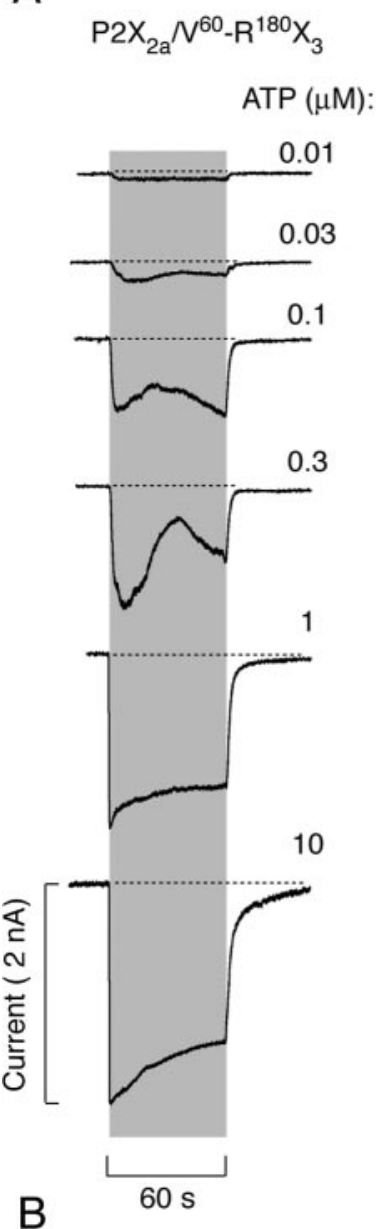

C
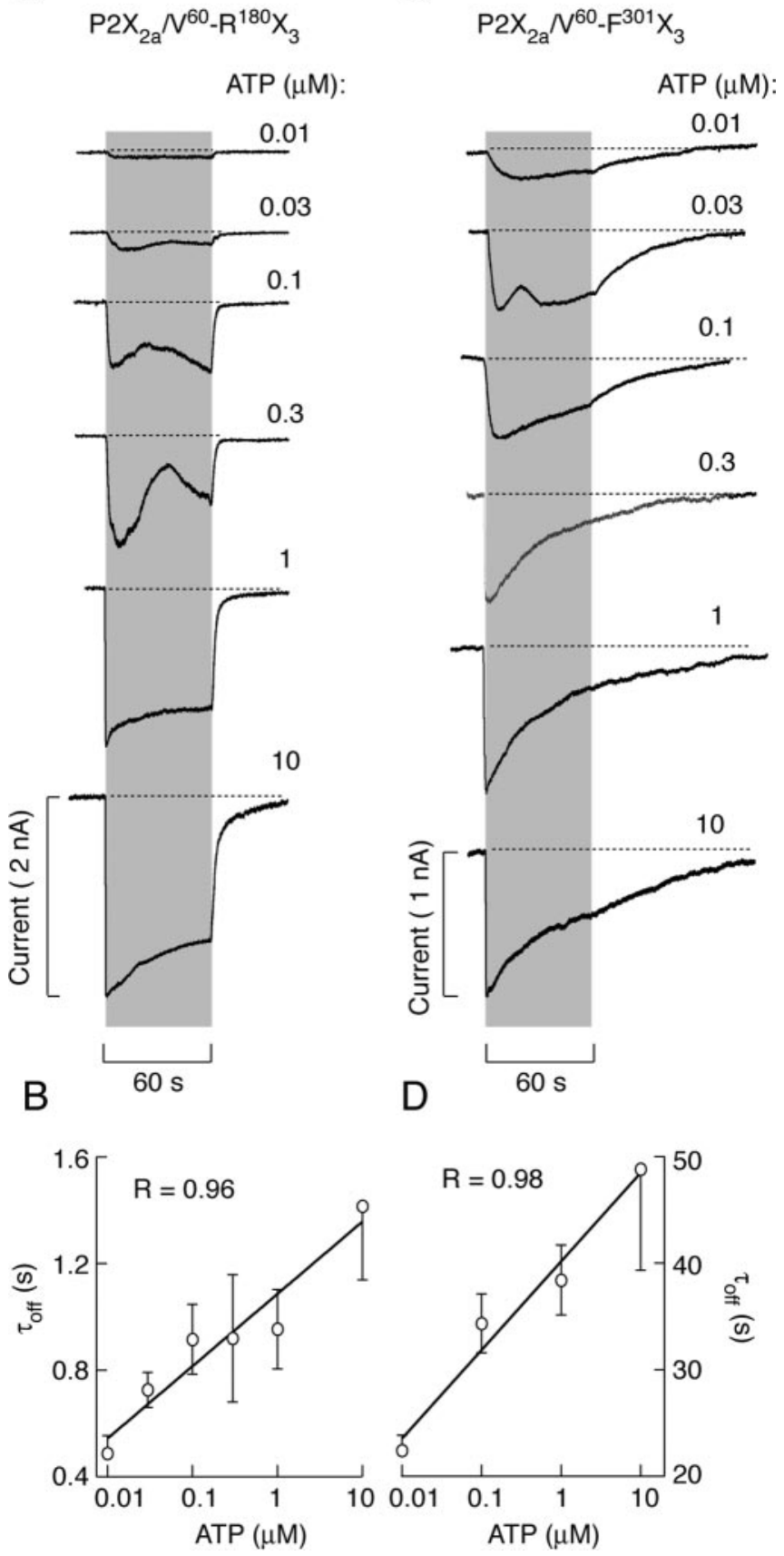

Figure 6. Concentration-dependent effects of ATP on the patterns of $\mathrm{P} 2 \mathrm{X}_{2 \mathrm{a}} / \mathrm{N} 60-\mathrm{R} 180 \mathrm{X}_{3}(A$, $B$ ) and $\mathrm{P} 2 \mathrm{X}_{2 \mathrm{a}} / \mathrm{V} 60-\mathrm{F} 01 \mathrm{X}_{3}(C, D)$ current signaling. $A$, Representative traces of $\mathrm{P} 2 \mathrm{X}_{2 \mathrm{a}} / \mathrm{N} 60-$ $\mathrm{R} 180 \mathrm{X}_{3}$ current from a single cell obtained during repetitive stimulation with increasing concentrations of ATP applied at 10 min interval. $B$, Correlation between ATP concentrations and $\tau_{\text {off }}$ values for $P 2 X_{2 a} / N 60-R 180 X_{3}$ (mean \pm SEM values, with $n$ between 4 and 26 per dose). C, Representative traces of $\mathrm{P} 2 \mathrm{X}_{2 \mathrm{a}} / \mathrm{V} 60-\mathrm{F} 301 \mathrm{X}_{3}$ current from different cells. D, Correlation between

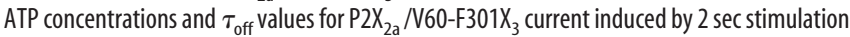
(mean \pm SEM values, with $n$ between 5 and 24 per dose). For correlation analysis, $\tau_{\text {off }}$ values were derived from monoexponential and biexponential fittings (for records induced by higher ATP doses) using the dominant $\tau_{\text {off } 1}$ component.

tervals between $30 \mathrm{sec}$ and 4 min were practically ineffective in resensitizing receptors. As with the $\mathrm{P}_{2} \mathrm{X}_{2 \mathrm{a}} / \mathrm{V} 60-\mathrm{F} 301 \mathrm{X}_{3}$ chimera, the extension of washing periods up to $40 \mathrm{~min}$ was not sufficient for full recovery from the desensitized state. These findings indicate that the $\mathrm{N}$ half of the $\mathrm{P} 2 \mathrm{XR}$ ectodomain region is influencing the stability of the desensitized conformation state.
A

B

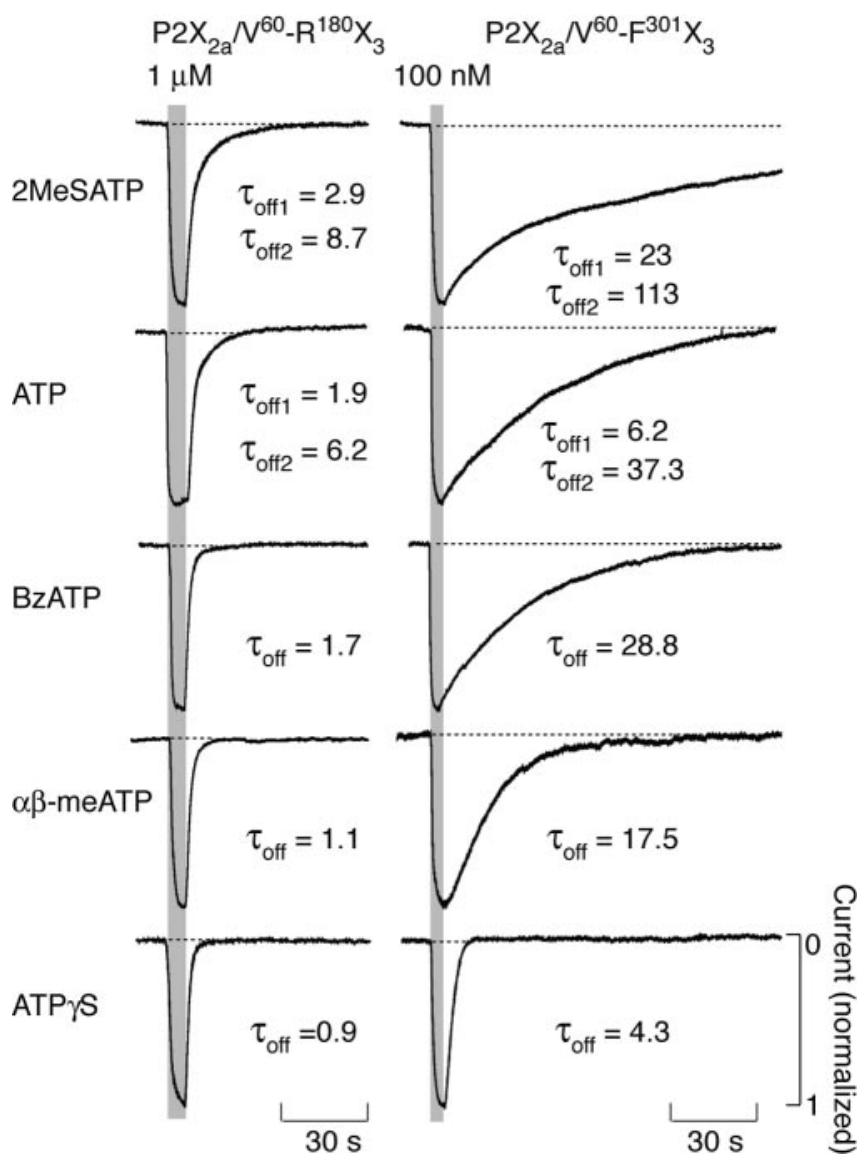

Figure 7. Agonist-specific decays in $\mathrm{P}_{2} \mathrm{X}_{2 \mathrm{a}} / \mathrm{N} 60-\mathrm{R} 180 \mathrm{X}_{3}(A)$ and $\mathrm{P} 2 \mathrm{X}_{2 \mathrm{a}} / \mathrm{N} 60-\mathrm{F} 301 \mathrm{X}_{3}(B)$ currents after short-term stimulation. Traces shown in $A$ are from a single cell obtained during repetitive stimulation at $10 \mathrm{~min}$ interval, whereas traces shown in $B$ are from different cells. The biexponential functions were the best fit for the effect of agonist withdrawal in all of the experiments with 2MeSATP and in a fraction of cells (35\%) with ATP applications. For all of the other agonists, the monoexponential functions were the best fit, and $\tau_{\text {off }}$ values were indicated below traces. Peak currents are shown as 1 .

\section{Discussion}

Here, we studied the gating properties of three chimeras to understand the influence of ectodomain structure and agonist potency on desensitization, deactivation, and resensitization of P2XRs. In our experimental conditions, the patterns of activation and desensitization of parental receptors were in general agreement with the literature (North, 2002). Furthermore, the estimated $\mathrm{EC}_{50}$ values for agonists at $\mathrm{P} 2 \mathrm{X}_{2}$ Rs found here were only slightly leftward shifted compared with other studies (Brake et al., 1994; King et al., 1996; Werner et al., 1996; Brandle et al., 1997; Zhou et al., 1998). For $\mathrm{P}_{2} \mathrm{X}_{3} \mathrm{R}$, differences were more significant; the reported $\mathrm{EC}_{50}$ values range from 0.2 to $1.8 \mu \mathrm{M}$ (Chen et al., 1995; Lewis et al., 1995; Garcia-Guzman et al., 1997; Wildman et al., 1999), whereas in our experimental conditions, the estimated $\mathrm{EC}_{50}$ value for ATP was $0.04 \mu \mathrm{M}$.

Several factors could contribute to the differences in the estimated $\mathrm{EC}_{50}$ values at $\mathrm{P} 2 \mathrm{X}_{2} \mathrm{R}$ and $\mathrm{P} 2 \mathrm{X}_{3} \mathrm{R}$. Recombinant receptors were studied when expressed in different cell types, and the host cells could influence the responses. In our experimental conditions, HEK293 (present study) and GT1 cells (He et al., 2002) expressing $\mathrm{P} 2 \mathrm{X}_{3} \mathrm{R}$ responded to ATP stimulation only if rapidly perfused with ATP-free medium for at least $10 \mathrm{~min}$ before re- 
A

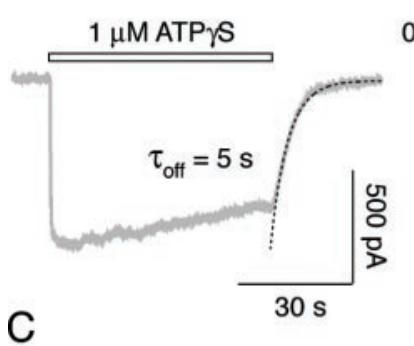

C
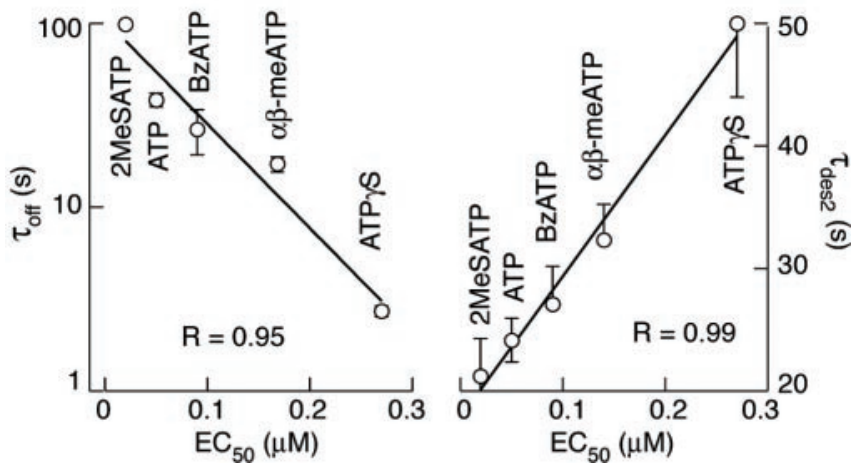

Figure 8. Dissociation between desensitization and deactivation rates of $\mathrm{P} 2 \mathrm{X}_{2 \mathrm{a}} / \mathrm{N} 60-\mathrm{F} 301 \mathrm{X}_{3}$ chimera. $A, B$, Relatively fast deactivation of ${\mathrm{P} 2 \mathrm{X}_{2 \mathrm{a}}}_{2} \mathrm{~N} 60-\mathrm{F} 301 \mathrm{X}_{3}$ chimera after washout of nondesensitizing ATP $\gamma S(A)$ and comparable desensitization $\left(\tau_{\text {des }}\right)$ and deactivation $\left(\tau_{\text {off }}\right)$ time

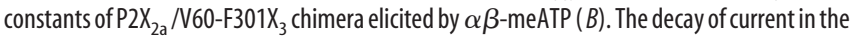
presence of $\alpha \beta$-meATP was fitted by a monoexponential function with a plateau at $52 \%$ of the peak current. C, Inverse linear-log correlation between $\mathrm{EC}_{50}$ and $\tau_{\text {off }}$ values. D, Linear relationship between $\mathrm{EC}_{50}$ and $\tau_{\text {des } 2}$ values. The $\tau_{\text {des }}$ and $\tau_{\text {off }}$ values were derived from experiments in which receptors were stimulated with saturating $(1 \mu \mathrm{M})$ concentrations of five agonists for 60 and $2-5$ sec, respectively. Data points and bars represent mean \pm SEM values, with $n=4-20$ per agonist.

cording or cultured in the presence of apyrase, an ectonucleotidase. Consistent with this, GT1 and HEK293 cells release ATP under resting conditions (He et al., 2004). Mammalian cells express one or several ectonucleotidase subtypes, which could compete with P2XRs for ATP at the plasma membrane (Zimmermann, 2000; Joseph et al., 2003). The estimated $\mathrm{EC}_{50}$ values for ATP thus may reflect the equilibrium between supply of ATP and its degradation. At low agonist concentrations, ectonucleotidase activity may also contribute to the generation of a biphasic response during the initial ATP application (Zemkova et al., 2003). It has also been suggested that this phenomenon might be attributable to a history-dependent increase in permeability of the pore (Khakh et al., 1999; Virginio et al., 1999).

As we reported previously (He at al., 2002), the substitution of native I66-H192 sequence with V60-R180 sequences of $\mathrm{P} 2 \mathrm{X}_{3} \mathrm{R}$ resulted in a leftward shift in the $\mathrm{EC}_{50}$ values for ATP, BzATP, and ATP $\gamma S$ at chimeric channels compared with parental $P 2 X_{2}$ Rs. Here, we show that the sensitivity of $\mathrm{P}_{2} \mathrm{X}_{2 \mathrm{a}} / \mathrm{V} 60-\mathrm{F} 301 \mathrm{X}_{3}$ and $\mathrm{P} 2 \mathrm{X}_{2 \mathrm{~b}} / \mathrm{V} 60-\mathrm{F} 301 \mathrm{X}_{3}$ chimeras to ATP, 2MeSATP, BzATP, $\alpha \beta$ -
A

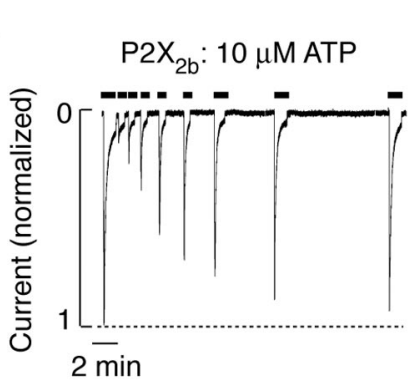

B

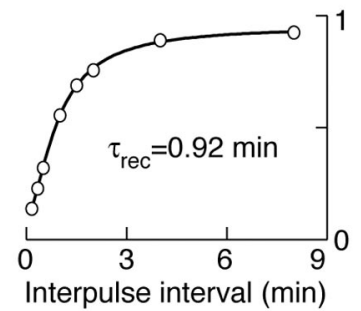

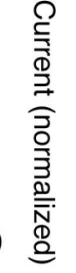

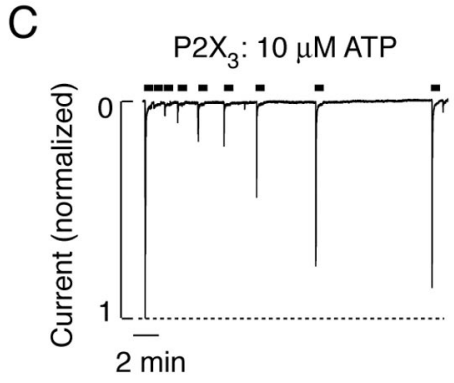

$\mathrm{D}$

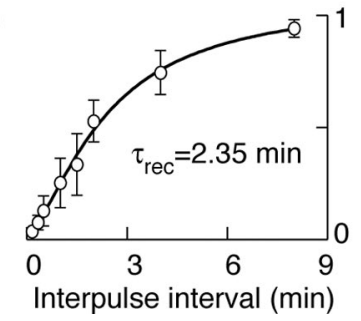

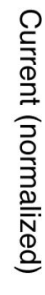

Figure 9. Recovery from desensitization of parental receptors. $A, C$, The example records showing $\mathrm{P}_{2 \mathrm{~b}}(A)$ and $\mathrm{P} 2 \mathrm{X}_{3}(\mathrm{C})$ current desensitization during 60 sec application of $10 \mu \mathrm{m}$ ATP and recovery of response to ATP after different washout times $(10,20,30,90,120,240$, and 480 sec). The bars above traces indicate time of ATP application. $B, D$, Recovery of responses to ATP in $P 2 X_{2 b} R(B)$ - and $P 2 X_{3} R(D)$-expressing cells, shown as the peak/first peak response and plotted as a function of washing time. Data (means $\pm S E M ; n=3-5$ ) were fitted as described in Materials and Methods.

meATP, and ATP $\gamma S$ is practically indistinguishable from that observed at $\mathrm{P} 2 \mathrm{X}_{3} \mathrm{R}$, suggesting that the selected ectodomain sequence of $\mathrm{P} 2 \mathrm{X}_{3} \mathrm{R}$ is sufficient to preserve the potency of agonists for receptors. The finding that $\mathrm{EC}_{50}$ values for agonists at $\mathrm{P} 2 \mathrm{X}_{2 \mathrm{a}} /$ V60-R $180 X_{3}$ chimera were between those observed at parental receptors, further indicates that both $\mathrm{N}$ and $\mathrm{C}$ halves of ectodomain participate in gating of P2XRs. This is in general accordance with studies showing that several residues in both ectodomain halves significantly affect the gating of receptors (Jiang et al., 2001; Roberts and Evans, 2004).

Changes in the ectodomain structure of $\mathrm{P} 2 \mathrm{X}_{2} \mathrm{Rs}$ also affected the rates of deactivation and recovery from desensitization states. The decay of current after removal of agonist is commonly used as a measure of receptor deactivation and in nondesensitizing receptors reflects the transition from open to closed conformation, followed by dissociation of the agonist from the closed channel. The decay in $\mathrm{P}_{2} \mathrm{X}_{2 \mathrm{a}} / \mathrm{V} 60-\mathrm{F} 301 \mathrm{X}_{3}$ and $\mathrm{P} 2 \mathrm{X}_{2 \mathrm{~b}} / \mathrm{V} 60$ $\mathrm{F}_{301 X_{3}}$ currents after agonist withdrawal was 15-200 times delayed. However, there was only a threefold delay in the decay of $\mathrm{P}_{2 \mathrm{X}} / \mathrm{a} 60-\mathrm{R} 180 \mathrm{X}_{3}$ current after ATP withdrawal compared with parental $\mathrm{P} 2 \mathrm{X}_{2 \mathrm{a}} \mathrm{R}$, indicating the relevance of the ectodomain $\mathrm{C}$ half in the stability of the open conformation state. Furthermore, the delay in $\mathrm{P}_{2} \mathrm{X}_{2 \mathrm{a}}$ /V60-F301X $\mathrm{X}_{3}$ current decay was dependent on

Table 2. The lack of correlation between $\mathrm{EC}_{50}$ and $\tau_{\text {off }}$ values for $\mathrm{P} 2 \mathrm{X}_{3}, \mathrm{P} 2 \mathrm{X}_{2 \mathrm{a}} / \mathrm{V} 60-\mathrm{F} 301 \mathrm{X}_{3}$, and $\mathrm{P} 2 \mathrm{X}_{2 \mathrm{a}} \mathrm{N} 60-\mathrm{R} 180 \mathrm{X}_{3}$ receptors in response to ATP and ATP $\gamma \mathrm{S}$ stimulation

\begin{tabular}{|c|c|c|c|c|}
\hline Receptor & ATP: $\mathrm{EC}_{50}(\mathrm{~nm})$ & ATP: $\tau_{\text {off }}(\mathrm{sec})$ & ATP $\gamma S: \mathrm{EC}_{50}$ (nм) & ATP $\gamma S: \tau_{\text {off }}(\mathrm{sec})$ \\
\hline $\mathrm{P}_{2} 2 \mathrm{X}_{3}$ & $39 \pm 7$ & $0.9 \pm 0.1(8)$ & $243 \pm 27$ & $0.6 \pm 0.1(5)$ \\
\hline $\mathrm{P} 2 \mathrm{X}_{2 \mathrm{a}} / \mathrm{V} 60-\mathrm{F} 301 \mathrm{X}_{3}$ & $48 \pm 6$ & $40.8 \pm 3.8^{*}(12)$ & $267 \pm 29$ & $3.6 \pm 0.3^{*}(10)$ \\
\hline $\mathrm{P} 2 \mathrm{X}_{2 \mathrm{a}} / \mathrm{V} 60-\mathrm{R} 180 \mathrm{X}_{3}$ & $352 \pm 18^{*}$ & $0.9 \pm 0.2(7)$ & $751 \pm 73^{*}$ & $0.8 \pm 0.1(15)$ \\
\hline
\end{tabular}

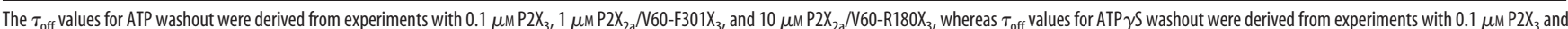
$\mathrm{P} 2 \mathrm{X}_{2 \mathrm{a}} / \mathrm{V} 60-\mathrm{F}_{301 X_{3}}$ and $1 \mu \mathrm{M} P 2 \mathrm{X}_{2 \mathrm{a}} / \mathrm{N} 60-\mathrm{R} 180 \mathrm{X}_{3}$. Numbers in parentheses indicate the number of records. $\mathrm{EC}_{50}$ values for ATP and ATP $\gamma \mathrm{S}$ are from Figure $1 \mathrm{C}$ and were derived from three to five experiments per dose.

${ }^{*} p<0.05$ versus $P 2 X_{3} R$. 

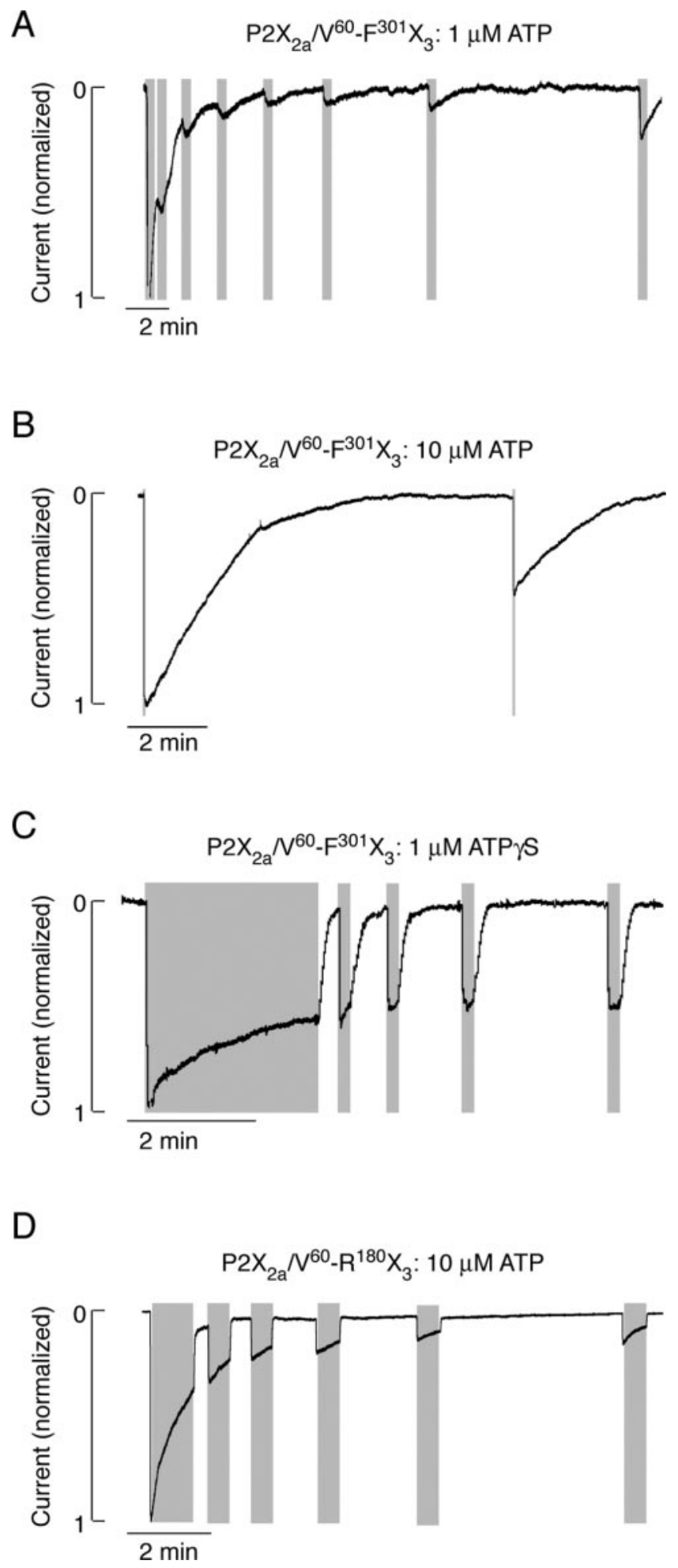

Figure 10. Recovery from desensitization of chimeric receptors. $A-C$, Patterns of $P 2 X_{2 a} /$ V60-F301X $X_{3}$ current signaling during repetitive stimulation with $1 \mu \mathrm{m} \operatorname{ATP}(A), 10 \mu \mathrm{m} \operatorname{ATP}(B)$, and $1 \mu \mathrm{M}$ ATP $\gamma S$ (C).D, P2X $2 \mathrm{a}$ /V60-R180X ${ }_{3}$ current signaling induced by repetitive application of $10 \mu \mathrm{M}$ ATP. Gray areas indicate the duration of agonist application. The rates of current deactivation are shown in Table 2.

the agonist used to activate receptors, but was not influenced by the duration of the agonist stimulation. Finally, the decay in currents reflected continuous desensitization and deactivation of receptors, and participation of deactivation in closure of channels inversely correlated with the potency of the agonists to activate receptor. Thus, changes in the stability of the open state could reflect on the probability of channels to enter the desensitized state after washout of agonist.

As discussed recently by Rettinger and Schmalzing (2004), one may propose two scenarios for deactivation of nondesensitizing P2XRs: (1) a channel-inherent slow transition from open to closed state, followed by a faster dissociation of agonist from receptor, or (2) fast channel closure, followed by slow dissociation of agonist from receptor. In both scenarios, the experimentally observed time course of current deactivation ultimately reflects agonist unbinding, but it does not clarify which transition is the rate-limiting step for this process (Colquhoun, 1998). Previously published studies by Hibell et al. (2001) revealed that the $\mathrm{P} 2 \mathrm{X}_{7} \mathrm{R}$ closure time was dependent on agonist potency. Rettinger and Schmalzing (2004) also found that the $\mathrm{EC}_{50}$ values for several agonists at a $\mathrm{P} 2 \mathrm{X}_{2} / \mathrm{X}_{1}$ chimera containing the ectodomain of $\mathrm{P} 2 \mathrm{X}_{1} \mathrm{R}$ inversely correlated with the rate of current decay after washout of the corresponding agonist, and suggested that agonist dissociation represents the rate-limiting step for current deactivation. As the authors stated, this conclusion should be taken with reservation, because they were unable to measure the deactivation properties of parental $\mathrm{P} 2 \mathrm{X}_{1} \mathrm{R}$ because of their rapid and complete desensitization.

We also observed a correlation between $\mathrm{EC}_{50}$ values for several agonists and their $\tau_{\text {off }}$ values for $\mathrm{P}_{2 \mathrm{X}_{2 \mathrm{a}}} / \mathrm{V} 60-\mathrm{F} 301 \mathrm{X}_{3}$ and $\mathrm{P} 2 \mathrm{X}_{2 \mathrm{a}} / \mathrm{V} 60-\mathrm{R} 180 \mathrm{X}_{3}$ chimeras and $\mathrm{P} 2 \mathrm{X}_{3} \mathrm{R}$, when analyzed separately, but in our experiments, the chimerization-induced shift in $\mathrm{EC}_{50}$ values for agonists did not reflect on rates of receptor deactivation. In contrast, a decrease in the potency of ATP and ATP $\gamma S$ for $\mathrm{P}_{2} \mathrm{X}_{2 \mathrm{a}} / \mathrm{V} 60-\mathrm{R}_{180 \mathrm{X}_{3}}$ chimera compared with $\mathrm{P} 2 \mathrm{X}_{3} \mathrm{R}$ was not accompanied with a decrease in $\tau_{\text {off. }}$. Furthermore, although $\mathrm{P} 2 \mathrm{X}_{3} \mathrm{R}$ and $\mathrm{P} 2 \mathrm{X}_{2 \mathrm{a}} / \mathrm{V} 60-\mathrm{F} 301 \mathrm{X}_{3}$ chimera have the same V60-F301 ectodomain sequence and ATP $\gamma \mathrm{S}$ was equipotent for two receptors, deactivation of the $\mathrm{P} 2 \mathrm{X}_{2 \mathrm{a}} / \mathrm{V} 60$ $\mathrm{F}_{301 \mathrm{X}_{3}}$ chimera was significantly slower than of the wild-type channel. In accordance with our findings, the affinity of agonists for $\mathrm{P} 2 \mathrm{X}_{7} \mathrm{R}$ is lower compared with $\mathrm{P} 2 \mathrm{X}_{3} \mathrm{R}$ and $\mathrm{P} 2 \mathrm{X}_{2} \mathrm{R}$ (North, 2002), but this channel deactivates with a time constant in seconds (Klapperstuck et al., 2001).

These results strongly argue against the hypothesis that agonist dissociation from its binding site represents the ratelimiting step for P2XR current deactivation. Our findings are more consistent with the general view for ligand-gated receptor channels that conformation changes associated with gating do not allow agonist dissociation (Chang and Weiss, 1999). We suggest that the stability of the open conformation state for P2XRs reflects on deactivation kinetics and dissociation of agonist from receptors. The gating-associated lock of agonists onto $\mathrm{P}_{2} \mathrm{X}_{2 \mathrm{a}} / \mathrm{V} 60-\mathrm{F} 301 \mathrm{X}_{3}$ and $\mathrm{P}_{2 \mathrm{X}} / \mathrm{V} 60-\mathrm{F} 301 \mathrm{X}_{3}$ chimeric channels lasts from three to tens of seconds, further indicating the potential validity of chimeras in studies on dissociation of ligands from receptors using radioligand-receptor binding measurements.

The observation that $\mathrm{P} 2 \mathrm{X}_{2} \mathrm{Rs}$ and $\mathrm{P} 2 \mathrm{X}_{3} \mathrm{R}$ recovered from desensitization completely and in a relatively short period $\left(\tau_{\text {rec }}, 2.3\right.$ min) suggests that internalization, which is a receptor-specific phenomenon and usually requires longer time periods (Ennion and Evans, 2001; Bobanovic et al., 2002), probably did not significantly participate in $\mathrm{P}_{2} \mathrm{X}_{2} \mathrm{R}$ and $\mathrm{P} 2 \mathrm{X}_{3} \mathrm{R}$ desensitization and recovery from desensitization. Others have also observed recovery of P2X $\mathrm{X}_{3} \mathrm{R}$ with similar $\tau_{\text {rec }}$ (Sokolova et al., 2004). However, the full recovery from desensitization of $\mathrm{P} 2 \mathrm{X}_{2 \mathrm{a}} / \mathrm{V} 60-\mathrm{F} 301 \mathrm{X}_{3}$ chime- 
ras needs $>40 \mathrm{~min}$, indicating that chimerization enhances the stability of the desensitized state. In contrast to the deactivation of channels, resensitization of chimeric channels is probably not a ligand-specific phenomenon. In addition, although $\mathrm{P} 2 \mathrm{X}_{2 \mathrm{a}} / \mathrm{V} 60$ $\mathrm{F}_{301 \mathrm{X}_{3}}$ and $\mathrm{P} 2 \mathrm{X}_{2 \mathrm{a}} / \mathrm{V} 60-\mathrm{R} 180 \mathrm{X}_{3}$ chimeras deactivated with different rates, they exhibited comparable rates of recovery from desensitization. This finding suggests the relevance of the $\mathrm{N}$ half of the ectodomain in conformation changes associated with desensitization and narrows the number of potential residues in additional site-directed mutagenesis studies. Because $\mathrm{P} 2 \mathrm{X}_{3} \mathrm{R}$ has the same sequence, but fully recovers within $10-15 \mathrm{~min}$, these results further indicate that the intramolecular interactions between the $\mathrm{N}$ half of the ectodomain sequence and other regions of the same subunits or between the subunits accounts for the specificity of receptor action.

In conclusion, we show here that the insertion of $\mathrm{P} 2 \mathrm{X}_{3} \mathrm{R}$ ectodomain in the backbone of $\mathrm{P} 2 \mathrm{X}_{2 \mathrm{a}} \mathrm{R}$ and $\mathrm{P} 2 \mathrm{X}_{2 \mathrm{~b}} \mathrm{R}$ effectively transfers the ligand-binding properties of $\mathrm{P} 2 \mathrm{X}_{3} \mathrm{R}$ to chimeric channels (in terms of potency of agonists), indicating the relevance of both ectodomain halves in ligand binding. Our results further indicate that changes in the receptor architecture made by chimerization dramatically increase the stability of opened and desensitized conformation states, as indicated by slow deactivation of receptors and recovery from desensitization after washout of agonist. The findings with chimeras that both ectodomain halves participate in gating, but that the $\mathrm{C}$ half influences stability of open conformation state and the $\mathrm{N}$ half of the ectodomain influences stability of the desensitized state, support the view that the occupancy of at least two binding sites is required for conformation transitions between the resting, conducting, and desensitized states of P2XRs.

\section{References}

Bean BP (1990) ATP-activated channels in rat and bullfrog sensory neurons: concentration dependence and kinetics. J Neurosci 10:1-10.

Bobanovic L, Royle SJ, Murrell-Lagnado RD (2002) P2X receptor trafficking in neurons is subunit specific. J Neurosci 22:4814-4824.

Boue-Grabot E, Archambault V, Seguela P (2000) A protein kinase C site highly conserved in P2X subunits controls desensitization kinetics of P2X 2 ATP-gated channels. J Biol Chem 275:10190-10195.

Brake AJ, Wagenbach MJ, Julius D (1994) New structural motif for ligandgated ion channels defined by an ionotropic ATP receptor. Nature 371:519-523.

Brandle U, Spielmanns P, Osteroth R, Sim J, Surprenant A, Buell G, Ruppersberg JP, Plinkert PK, Zenner HP, Glowatzki E (1997) Desensitization of the $\mathrm{P} 2 \mathrm{X}_{2}$ receptor controlled by alternative splicing. FEBS Lett 404:294-298.

Chang Y, Weiss DS (1999) Channel opening locks agonist onto the $\mathrm{GABA}_{\mathrm{C}}$ receptor. Nat Neurosci 2:219-225.

Chen C-C, Akopian AN, Sivilotti L, Colquhoun D, Burnstock G, Wood JN (1995) A P2X purinoreceptor expressed by a subset of sensory neurons. Nature 377:428-431.

Clarke CE, Benham CD, Bridges A, George AR, Meadows HJ (2000) Mutation of histidine 286 of the human $\mathrm{P}_{2} \mathrm{X}_{4}$ purinoreceptor removes extracellular pH sensitivity. J Physiol (Lond) 523:697-703.

Coddou C, Morales B, Gonzalez J, Grauso M, Cordillo F, Bull P, Rassendren F, Huidobro-Toro JP (2003) Histidine 140 plays a key role in the inhibitory modulation of the $\mathrm{P} 2 \mathrm{X}_{4}$ nucleotide receptor by copper but not zinc. J Biol Chem 278:36777-36785.

Colquhoun D (1998) Binding, gating, affinity and efficacy: the interpretation of structure-activity relationship for agonists and of the effects of mutating receptors. Br J Pharmacol 125:924-947.

Egan TM, Haines WR, Voigt MM (1998) A domain contributing to the ion channel of ATP-gated $\mathrm{P} 2 \mathrm{X}_{2}$ receptors identified by the substituted cysteine accessibility method. J Neurosci 18:2350-2359.
Ennion SJ, Evans RJ (2001) Agonist-stimulated internalisation of the ligand-gated ion channel $\mathrm{P}_{2} \mathrm{X}_{1}$ in rat vas deferens. FEBS Lett 489:154-158.

Garcia-Guzman M, Stuhmer W, Soto F (1997) Molecular characterization and pharmacological properties of the human $\mathrm{P}_{2} \mathrm{X}_{3}$ purinoreceptor. Brain Res Mol Brain Res 47:59-66.

He M-L, Koshimizu T, Tomic M, Stojilkovic SS (2002) Purinergic P2X receptor desensitization depends on coupling between ectodomain and C-terminal domain. Mol Pharmacol 62:1187-1197.

He M-L, Zemkova H, Koshimizu T, Tomic M, Stojilkovic SS (2003) Intracellular calcium measurements as a method in studies on activity of purinergic P2X receptor channels. Am J Physiol 285:C467-C479.

He M-L, Iglesias-Gonzalez A, Stojilkovic SS (2004) Release and extracellular metabolism of ATP by ecto-nucleotidase eNTPDase 1-3 in hypothalamic and pituitary cells. Paper presented at Fourth International Symposium of Nucleosides and Nucleotides, Chapel Hill, NC, June.

Hibell AD, Thompson KM, Simon J, Xing M, Humphrey PPA, Mitchel AD (2001) Species- and agonist-dependent differences in the deactivationkinetics of $\mathrm{P} 2 \mathrm{X}_{7}$ receptors. Naunyn Schmiedebergs Arch Pharmacol 363:639-648

Jiang L-H, Rassendren F, Spelta V, Surprenant A, North RA (2001) Amino acid residues involved in gating identified in the first membranespanning domain of the rat $\mathrm{P}_{2} \mathrm{X}_{2}$ receptor. J Biol Chem 276:14902-14908.

Joseph SM, Buchakjian MR, Dubyak GR (2003) Colocalization of ATP release sites and ecto-ATPase activity at the extracellular surface of human astrocytes. J Biol Chem 278:23331-23342.

Khakh BS, Proctor WR, Dunwiddie TV, Labarca C, Lester HA (1999) Allosteric control of gating and kinetics at $\mathrm{P} 2 \mathrm{X}_{4}$ receptor channels. J Neurosci 19:7289-7299.

Khakh BS, Burnstock G, Kennedy C, King BF, North RA, Seguela P, Voigt M, Humphrey PPA (2001) International union of pharmacology. XXIV. Current status of the nomenclature and properties of P2X receptors and their subunits. Pharmacol Rev 53:107-118.

King BF, Ziganshina LE, Pintor J, Burnstock G (1996) Full sensitivity of $\mathrm{P}_{2} \mathrm{X}_{2}$ purinoreceptor to ATP revealed by changing extracellular $\mathrm{pH}$. Br J Pharmacol 117:1371-1373.

Klapperstuck M, Buttner C, Schmalzing G, Markwardt F (2001) Functional evidence of distinct ATP activation sites at the human $\mathrm{P} 2 \mathrm{X}_{7}$ receptor. J Physiol (Lond) 534:25-35.

Koshimizu T, Tomic M, Van Goor F, Stojilkovic SS (1998) Functional role of alternative splicing in pituitary $\mathrm{P}_{2} \mathrm{X}_{2}$ receptor-channel activation and desensitization. Mol Endocrinol 12:901-913.

Koshimizu T, Koshimizu M, Stojilkovic SS (1999) Contributions of the C-terminal domain to the control of $\mathrm{P} 2 \mathrm{X}$ receptor desensitization. J Biol Chem 274:37651-37657.

Koshimizu T, Ueno S, Tanoue A, Yanagihara N, Stojilkovic SS, Tsujimoto G (2002) Heteromultimerization modulates P2X receptor functions through participating extracellular and C-terminal subdomains. J Biol Chem 277:46891-46899.

Lester RA, Jahr CE (1992) NMDA channel behavior depends on agonist affinity. J Neurosci 12:635-643.

Lewis C, Neidhart S, Holy C, North RA, Buell G, Surprenant A (1995) Coexpression of $\mathrm{P}_{2} \mathrm{X}_{2}$ and $\mathrm{P} 2 \mathrm{X}_{3}$ receptor subunits can account for ATPgated currents in sensory neurons. Nature 377:432-435.

Li C, Peoples RW, Weight FF (1997) $\mathrm{Mg}^{2+}$ inhibition of ATP-activated current in rat noduse ganglion neurons: evidence that $\mathrm{Mg}^{2+}$ decreases the agonist affinity of the receptor. J Neurophysiol 77:3391-3395.

Nicke A, Baumert HG, Rettinger J, Eichele A, Lambrecht G, Mutschler E, Schmalzing G (1998) P2 $\mathrm{X}_{1}$ and $\mathrm{P} 2 \mathrm{X}_{3}$ receptors form stable trimers: a novel structural motif of ligand-gated ion channels. EMBO J 17:3016-3028

North RA (2002) Molecular physiology of P2X receptors. Physiol Rev 82:1013-1067.

Ralevic V, Burnstock G (1998) Receptors for purines and pyrimidines. Pharmacol Rev 50:413-492.

Rassendren F, Buell G, Newbolt A, North RA, Surprenant A (1997) Identification of amino acid residues contributing to the pore of a $\mathrm{P} 2 \mathrm{X}$ receptor. EMBO J 16:1446-3454.

Rettinger J, Schmalzing G (2004) Desensitization masks nanomolar potency of ATP at the P2X $\mathrm{X}_{1}$ receptor. J Biol Chem 279:6426-6433. 
Roberts JA, Evans RJ (2004) ATP binding at human P2X receptor: contribution of aromatic and basic amino acids revealed using mutagenesis and partial agonists. J Biol Chem 279:9043-9055.

Simon J, Kidd EJ, Smith FM, Chessell IP, Murrell-Lagnado R, Humphrey PPA, Barnard EA (1997) Localization and functional expression of splice variants of the $\mathrm{P}_{2} \mathrm{X}_{2}$ receptor. Mol Pharmacol 52:237-248.

Sokolova E, Skorinkin A, Fabbretti E, Masten L, Nistri A, Giniatullin R (2004) Agonist-dependence of recovery from desensitization of $\mathrm{P}_{2} \mathrm{X}_{3}$ receptors provides a novel and sensitive approach for their rapid up or downregulation. Br J Pharmacol 141:1048-1058.

Virginio C, MacKenzie A, Rassendren FA, North RA, Surprenant A (1999) Pore dilation of neuronal P2X receptor channels. Nat Neurosci 2:315-321.
Werner P, Seward EP, Buell GN, North RA (1996) Domains of P2X receptors involved in desensitization. Proc Natl Acad Sci USA 93:15485-15490.

Wildman SS, King BF, Burnstock G (1999) Modulatory activity of extracellular $\mathrm{H}^{+}$and $\mathrm{Zn}^{2+}$ on ATP-responses at $\mathrm{rP}_{2} \mathrm{X}_{1}$ and $\mathrm{rP} 2 \mathrm{X}_{3}$ receptors. $\mathrm{Br} \mathrm{J}$ Pharmacol 128:486-492.

Zemkova H, He M-L, Stojilkovic SS (2003) Ecto-nucleotidases control the pattern of signaling by $\mathrm{P} 2 \mathrm{X}$ receptor at nanomolar ATP concentrations. Soc Neurosci Abstr 29:250.7.

Zhou Z, Monsma LR, Hume RI (1998) Identification of a site that modifies desensitization of $\mathrm{P} 2 \mathrm{X}_{2}$ receptors. Biochem Biophys Res Commun 252: 541-545.

Zimmermann H (2000) Extracellular metabolism of ATP and other nucleotides. Naunyn Schmiedebergs Arch Pharmacol 362:299-309. 